NBER WORKING PAPER SERIES

\title{
AGGLOMERATION AND THE \\ PRICE OF LAND: EVIDENCE \\ FROM THE PREFECTURES
}

Robert Dekle

Jonathan Eaton

Working Paper No. 4781

\section{NATIONAL BUREAU OF ECONOMIC RESEARCH 1050 Massachusetts Avenue \\ Cambridge, MA 02138 \\ June 1994}

We thank Aditya Bhattacharjea, Rabindra Bhandari, and Akiko Tamura for excellent research assistance and seminar participants at the Board of Governors of the Federal Reserve System, Tufts University, Tel Aviv University, New York University, Harvard University, Indiana University, and participants at the conference "Asset and Land Prices: Conceptual Issues and the Japanese Experience," Boston University, for comments. We gratefully acknowledge the support of the Japan-U.S. Friendship Commission and the National Science Foundation. This paper is part of NBER's research program in Intermational Trade and Investment. Any opinions expressed are those of the authors and not those of the National Bureau of Economic Research. 


\title{
AGGLOMERATION AND THE \\ PRICE OF LAND: EVIDENCE \\ FROM THE PREFECTURES
}

\begin{abstract}
We use Japanese prefectural wage and land price data to estimate the magnitude of agglomeration effects in manufacturing and finance. We also examine the range of agglomeration effects by estimating the extent to which they diminish with distance, using a specification that encompasses the polar cases of purely local agglomeration economies, on the one hand, and national increasing returns to scale, on the other. We find that agglomeration effects are slightly stronger in financial services than in manufacturing, and that they diminish substantially with distance in either sector. Our estimates indicate that agglomeration effects can explain about 5.6 per cent of the growth in Japanese output per worker in manufacturing and about 8.9 per cent of the growth in output per worker in financial services during 1976-1988. Our estimates imply that, while the average elasticity of productivity with respect to agglomeration is between 10 and 15 per cent, agglomeration economies in the largest prefectures are nearly exhausted.
\end{abstract}

Robert Dekle

Department of Economics and International Relations

Boston University

270 Bay State Road

Boston, MA 02138
Jonathan Eaton

Department of Economics

Boston University

270 Bay State Road

Boston, MA 02138

and NBER 
1. Introduction

A number of explanations of economic growth focus on Increasing returns to sale external to the firm as a source of Increased productivity.' Extermal effects also play a central role in the literature on urban location, where they provide an explanation for the existence of citiea. ${ }^{2}$ Indeed, Lucas (1988) notes the similarity of his explanation of economic growth and explanations for c1ties:

It seems to me that the 'force' ve need to postulate for the central role of clties in economic life is of exactly the ame character as the 'external human capital. I have postulated as force to account for certain features of aggregative development. If 00 , then land rents should provide an Indirect measure of this force....(p. 39)."

The two literatures differ in two baslc respects, however. For one thing, the growth 11 terature has assumed externalities at the aggregate level, whlle the urban 11 terature treats external1tles as local. Second, most models of growth have not incorporated a productive role for land; all factors of production except labor are reproducible. Hence there is no natural $11 \mathrm{mlt}$ to the supply of complementary factors avallable to an individual worker.

However, not surprisingly, land playa a central role in the urban literature. The competition among factora for scarce land in an

ISec, for example, Arrow (1962), Romer (1986), and Lucas (1988).

2Examples of models that focus on externalitles at the urban level are M111s (1967), Amott (1979), Helpman and PInes (1980), and Henders on (1988). Henderson (1987) aurveys this 11 terature. 
urban location provides a centrifugal force to offset centripetal agglomeration effects. Congestion effects explain the existence of multiple cltles and economic activity in nonurban locations. If agglomeration effects are nover offset by competition for ecarce land then activity should converge to a single polnt that would become a "black hole" of economic activity. Presumably the IImftations on economic activity lmplled by finite natural resources act as a constraint on economlc growth as well.

Data on urban activity over time and acrose countries indlcate a strong correlation between economlc growth and urbenlzation. This relationship suggests that the benefits of proximlty increasingly outwelgh the costs of congestion as aconomles develop."

The relationship between urbanlzation and growth has been attributed to varlous Interreleted factors." One 1s local ecale economles, both internal and external to the firm, In Industrial activity (as modeled, for Instance, by Henderson (1988)). Another explanation is that the increased speciallzation of labor and differentiation of colmoditles assoclated with development make trade at a central location more deglrable (as suggested, for example, by Dlamond's (1982) models of search). The first argument explains urbanization and clty size by the development of particular industries. Sassen (1991), for example, relates the most recent growth of New York, Londion, and Tokyo to the growth of international finance." The second suggests that urbanization is

\footnotetext{
'Kuznets (1966, PP. 272-273) found that the per cent of the population living In urban locations grew substantially between the beginning and the middle of the twentleth century in all of a sample of twelve now Industrialized countries. Chenery and Syrquin (1975), applying pooled time-serles cross-nectional regression analysis to international data, found that the population of a typlcal country became more than 50 per cent urban once 1 ts per caplta Income exceeded $\$ 500$ (In 1964 US $\$$ ). and tapered off at 75 per cent once per caplta GNP exceeded $\$ 2000$.

'Jacobs (1969, 1984) 1s, of course, the basic reference.

Boone (1989) finds that higher land prices in Japanese prefectures are
} 
likely to be assoclated with egglomerations of more apeclallzed, and more educated, Individuals (as suggested by Glaeser et.al. (1991)).

The lack of comprehensive, uniform data on land rents or prices across tiwe and space has impeded serlous Imvestgation of the extent and range of agglomeration effects on productivity. An exception to this absence of data 1s Japan, where the Economic Planning Agency of the Government of Japan has reported commercial and residential property values by prefecture ince the early 2970s. Given the enormout range in the intensity of land use across the 46 prefectures of the Japanese archipelago, these data provide an excellent source of Information on agglomeration effects. Our purpose here is to explo1t these data to measure the Intensity and scope of the effects of agglomeration on productivity.

We proceed as follows. In Section 2 ve develop a model of Industry production with positive production externalities among firms: Moro production by one firm ralses productivity in firms nearby. The effect diminishes across space. The model encompasses the two polar cases that have received the most attention:

In one, agglomeration effects are completely local, with possible positive splllovers between firms within a region but not across reglons. The urban economics literature has devoted the most attention to this case. Ciccone and Hall (1993) have recently estimated the extent of splllovers of this type with U.S. county and state data, finding an elasticlty with respect to density of .04. A malntained assumption 1. that aplllovers are purely local.

In the other polar case, splllover effects are nationwide, with distance 1mposing no 1mpediment. The international trade and macroeconomics literature associated with greater production of financlal services. 
has focused on externalities of thle type." Caballero and Lyons (1992) recently estlmated the external economles In U.S. manufacturing as a whole at about 20 to 30 per cent. '

In Section 3 we describe how we use the podel to infer the magnitude and geographlcal reach of external economles fron Japanese prefectural data on land prices, wages, outputs, and reglonal characterlstica. We use annual data for the perlod 1976 through 1988. Because of spectacular growth in the output of financial services in Japan during this period, and the attention given to It by Sassen (1991) and Boone (1989), we estimate tha extent and range of aglomeration offects in manufacturing and financial services separately.

Section 4 analyses our results. We find elasticitles of productivity with respect to local activity between 10 and 15 per cent in manufacturing and between 12 and 20 per cent in finance. Our estimates of the elasticities vith respect to nationwide activity are about 2 to 5 per cent higher in each case. For both sectors we find that the Impact of agglomeration on productivity dininishes substantially with distance. Activity $10 \mathrm{klloweters}$ away has half or less the 1mpact of activity in the Imediate vicinity. The estimated effect of egglomeration on productivity is within two per cent of the theoretical maximum 1mplied by our specification for the largest prefectures, but only about threo-fourths of the theoretical maximum in prefectures with the amallest agglomeration offects. Agglomeration Influences the comparative advantage of prefectures as financial and manufacturing centera, and we discusa how this comparative advantage has shifted over time. Our estimates Imply that Increased agglomeration can explain about 5.6 per cent of the

\footnotetext{
'Helpman (1984) survey modela of International trade with positive production externalities.

The focus on economles of agglomeration across space rather than over time. Henderson (1994) hag recently estimated the extent of temporal rather than spatial decay of agglomeration effects.
} 
growth of output per worker in manufacturing and about 8.9 per cent of the growth of output per worker in finsnce during the period that we examine. Section 5 discusses some Implications of our results.

2. A Model of Prefectural Production and Land Rents

We first discuss the theoretical framework that we use to estimate the extent and range of agglomeration effects in manufacturing and finance. As is standard in much of the literature on externalities, we treat technology at the plant level as linear homogeneous in the plant's inputs, but allow productivity at the plant level to depend on the general level of activity at nearby plants in that industry in the region. Specifically, we measure the agglomeration economies provided by prefecture $p$ in industry 1 with the index:

$$
\Lambda_{1 p}-\sum_{j=1}^{46} \frac{Y_{11}}{\left(1+\delta_{1} d_{p j}\right)^{2}}
$$

where $Y_{1 f}$ is a measure of the overall activity of industry 1 in prefecture $J$, and $d_{p j}$ is the distance between prefecture $p$ and prefecture 1 . At one extreme, if $\delta$ then aglomeration economies are purely local in nature: Increased activity in neighboring prefectures creates no externalities. At the other extreme, if $\delta$ - 0 then increased activity in this industry anywhere In the country increases productivity in prefecture p to the same extent: Extemal economies are then nationwide."

We Introduce agglomeration effects into the production function as

\footnotetext{
- "Gravity" models of international trade employ a similar specification to estimate trade Intensity between countries: Intensity increases with the product of the trading partners' incomes but diminishes with the distance between them. Deardorff (1984) discusses the model and 1ts origins.
} 
follows: Output $y_{f 1 p}$ of plant $f$ in Industry 1 producing in prefecture $p$, as a function of 1ts inputa $k_{f 1 p}$ of capital, $l_{f 1 p}$ of labor, and $t_{f i p}$ of land, and prefactural agglomeration in that industry, $A_{1 p}$, 1s:

$$
y_{f 1 p}=0^{-\phi_{1} / \Lambda_{1 p}} \varphi_{1}\left(k_{f 1 p}, l_{f 1 p}, t_{f 1 p}\right) \phi_{1}\left(c_{p}, t\right) U_{1 p t}
$$

where:

$$
\varphi_{1}(k, 1, t)-k^{1-\beta_{L 1}-\beta_{T 1}}{ }_{1}^{\beta_{L 1}} \beta_{T}^{\beta_{T 1}} .
$$

Here $\phi_{1}$ captures the extent of external economies in Industry 1 and $\beta_{L 1}$. $\beta_{T 1}$, and $1-\beta_{L 1}-\beta_{T 1}$ are factor shares for that industry. The function $p_{1}$ contalns time and prefectural characterlatics $c_{p}$ that affect productivity as arguments. The term $U_{\text {lpt }}$ is a lognomally distributed error.

We adapt this functional form for the contribution of external economies from Henderson (1987). Th1s specification lmplles that the elasticlty of productivity with respect to total economic activity is large at low levels of activity and diminishes with increased economic activity as the contribution of agglomeration reaches its theoretical maximum of one. The specification differs, for example, from what 1. Implled by the Dixit-Stiglitz (1977) model of product differentlation, whlch has been applled to urban analysis by fujlta (1988). Tro simple microeconomic models that yleld this speciflcation are the following:

\footnotetext{
-If production 1s Cobb-Douglas and all factors except land are mob1lo then the elastlclty of production with respect to urban activity must diminish for cities of finlte ize to emerge. If external effects have a constant elasticlty that 1s lower than the land sharo then activity will spread out evenly across apace, whlle if the elastcity exceeds the land share it will collapse to aingle point. See Henderson's (1987) discussion.
} 
One model captures the ame Smithian notion that productivity increases with the division of labor among planta as the Dixit-stiglitz (1977) framework. Specifically, ay that the output $y_{f}$ of plant $f$ is a function of the number of plants $N$ in 1 ts industry from which it buys inputs to produce 1ts own output. In particular, let:

$$
y_{f}-\sum e^{-\phi / N} \varphi_{1}\left(k_{f}, 1_{f}, t_{f}\right) .
$$

If the minimum efficlent plant alze in the industry is $X_{1}$, then the number of plants in a prefecture will be proportional to Industry output. Say that the output of a plant used as an Input elaewhere is tradable at zero cost over a radius $r$. Also assume that it is so expensive to trade the output over a larger radius that it is not worth using elsewhere. If $r$ has distribution $1-1 /(1+\delta r)^{2}$, then the probabll1ty that that a plant w11l buy from another plant a diatance $r$ away 1: $1 /(1+\delta r)^{2}$. Together these assumptions imply the specification that we use here.

rarket Information

Another motivation for this epecification is the superior knowledge about market conditions provided by greater levels of economic activity. Say, for example, that consumers desire a characteristic of a product ot at time $t$, and that ovolves continuously according to the random walk process:

$$
d \theta t-o d z
$$


where 2 is a standard normal wiener process. Consumers value a commodity embodylng characteristic os equivalent to $e^{-(\theta-\theta *)^{2}}$ of a product embodying characterlstic $0 *$. Hence producers of a product with characterlstic o w111 have to price it at a discount of $e^{-(1-8 *)^{2}}$. Plants can embody any value of In their products at equal cost.

Producers form their bellefs about by observing the price at which products of different qualitios are sold. The most recent observation providea the best estimate of the current value of $\theta$, and w11l predict the current value with varlance $\sigma^{2} t$, where $t$ is the time that has lapged alnce that transaction.

Suppose that the frequency of trangactions in a prefecture is proportional to economic activity in the Industry there, with a share $1 /(1+\delta r)^{2}$ of trangactions observed in a prefecture a distance $r$ away. Under these assumptions, firms in prefecture $p$ wlll have a forecast error that is proportional to $1 / \Sigma Y_{j} /\left(1+\delta d_{p j}\right)^{2}$. The average value of their products will fall as this forecast orror rises according to the specification in equation (2).

3. Data and Estimation

Our task is to estimate the parameters and $\delta$ from Japanese prefectural data. We do so not by estimating the production function in equation (2), but by estimating the corresponding cost function. Cost mininization by firms Implies that prefectural external economios and prefectural production amentiles should exactly offset differences in factor costs across prefectures. Our procedure is to rolate prefectural factor cost to external economles and prefectural amenities in order to ostlmate and $\delta$. 
We use data for the perlod 1976-1988.10 Hence we have a panel with 598 observatlons (46 prefectures over 13 yeara). All data are In 1980 real yen"t.

gectoral Decomposition

We estimate the parameters and 6 for manufacturing and for financial services separately. Of the remaining sectora listed in Table 1, we remove agriculture and mining from the anelyale. Both contribute negliglbly to output and employment, and wo regard the determination of their location as largely Independent of the agglomeration and congestion effects that we address here. 12

of the remaining sectors, we treat (1) manufacturing and (2) finance and Insurance as producing output that 10 primarlly tradable among prefectures, and subject to the external economlea modeled In Section 3 . We treat the remalning 6 sectors as producing outputs that are nontradable, selling elther to businesses or to households within the prefecture. We assume that these aectors produce at constant returns to ecalo at both the plant and Industry levels, so are not themselves aubject to external economles.

10 Prior to 1975 the sectoral decomposition of prefectural value added was not consistent with the decomposition of the prefectural labor force.

1We obtalned annual prefectural consumer price Indices from varlous 1 ssues of the Jepan statistleal Iearbook.

12 In 1988 agrlcultural production was 2.7 per cent and minlng was 0.3 per cerit of Japanese GDP. Japanese tax pollcy treats agricultural land that was in agricultural use before 1950 very favorably relative to other land.

Agricultural land is taxed at a lower rate than the sandard tax and at 1.4 per cent of Ita asseaned value. In most cases, agricultural land Is exempt from Inheritance taxes. We treat conversion of agricultural land to other uses as exogenous (determined, for example, by government policles) rather as the outcome of market forces. (Nevertheless, the anticlpation that policles that protect agricultural land mlght be removed could have a 8 igniflcant effect on nonagricultural land prices. In particular, tending to depress them In prefectures where agricultural land is more plentiful.) 
Local Pactor cost

We treat capital as completely moblle across prefectures, wo that plants everywhere face the same cost of capital. Time effecte thus plck up the effect of variations in the cost of capltal over time. Hence only differences in wages and land rents creato varlation in local factor costs across prefectures. In order to obtain eutimates of the cost of production by prefecture for manufacturing and financlal vervices, then, we need to measure vage and land rente by prefecture, and their local (direct and Indlrect) shares in production.

Wages

Wages by Industry and prefecture for the two traded and $\$ 1 x$ nontraded sectors are calculated as the average labor cost per worker. 13

\section{Land Rent:}

The user cost of land is the rent, but we could only obtaln comprehensive data on land prices. 14 Denoting the rent during perlod $t$ a $R_{t}$, the price of land In perlod $t$ as $P_{t^{\prime}}$ and the nominal opportunity cost of capltal as $r_{t^{\prime}}$ the magnitudes are related by:

\footnotetext{
13e obtalned the average labor cost per worker in each prefecture from the Ansual Report on prefectural dccounte. The number of workers in each sector by prafecture Is taken from the Japen statiotical roarbook.

14 We obtain annual prefectural land prices by dividing private land values by the private usable land area of the prefecture. We take private prefectural land values from the Economlc Planning Agency's Annual Report on the National Accounte. Prefectural usable land areas are from the Japan statigtical Yoarbook.
} 


$$
R_{t}-r_{t} P_{t}-P_{t+1}^{e}-P_{t^{\prime}}
$$

where $P_{t+1}^{0}$ is the price of land in that in expected in period $t+1$. We use the expected return on the etock market as our cost of capltal varlable. ${ }^{25}$ We infer the expected land rent by estimating the equation:

$$
\ln \left(r_{t}-\frac{P_{p t+1}-P_{p t}}{P_{p t}}\right)-\mu_{t} D_{t}+\mu_{r} D_{p r}+u_{p t}
$$

on our prefectural panel. Here $\mu_{p r}$ is the coefficlent of the dummy variable $D_{p r}$ that Indicates the prefecture's region, $\mu_{t}$ is the coefficient on the time dummy $D_{t}$, and $u_{p t}$ is the error. ${ }^{10}$ We use the forecast from this equation as our measure of local factor cost. We octimate this equation simultaneously with our estimation of the cost functions in manufacturing and in financial enrvices.

ractor ahares

We weight land and labor costs by their direct and indirect shares in production for each sector, using the 1980 national input-output matrix. ${ }^{29}$ We partition this matrix botween 1ts two traded and six nontraded components as:

\footnotetext{
18 We obtained this measure by estimating the total return on equity (dividends plus capital gain) as. first order autoregressive moving average process. We then used the one-perlod-ahead forecast as the expected return on capital. Data on the total return on equity are from Hemso and Ibbotson (1989).

1"Regional dumiles are based on our division of the Japanese archipelago into ten raglons: hokkaldo, Tohoku, hokurlku, Kanto (other than greater Tokyo), Greater Tokyo, Toka1, KInk1, Chugoku, Sh1koku, and Kyushu. Table Al shows how we assigned individual prefectures to these reglons.

1"The input-output matrix is frow the lnsual Report on National Accounts.
} 


$$
\left[\begin{array}{ll}
A_{\text {TI }} & A_{\text {TN }} \\
A_{N T} & A_{\text {NN }}
\end{array}\right] \text {. }
$$

The total share of factor $n$ in sector 1 , then, is $\bar{\beta}_{1 \mathrm{~m}}$ given by:

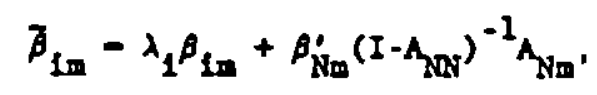

where $\beta_{\text {in }}$ 1. the direct, ahare of factor a In value added in Industry $1, \lambda_{1}$ is the share of value added in the output of Industry $1, \beta_{\mathrm{N}}^{\prime}$ is a $6 \times 1$ colum vector of the direct shares of factor $n$ In the nontraded sectors, and A Is the $6 \times 1$ vector of the corresponding shares of nontraded sectors in producing the output of sector 1 .

We calculate direct factor shares In value added for each of the olght sectors from national Income accounts data from 1981 to 1985 . The labor share In production for each sector is taken from national accounts data on wage payments by sector. Data on the reproductble capltal stock by sector are multiplied by the long-term real interast rate to provide an estimate of tho share of reproducible capital." We treat the residual as the land share.

Industry Activity

Wo employ two different meagures of Industry activity. One is aimply Industry value added in the prefecture. The other is the density of industry. value added, or value added per unit of usable land.1" Which measure is wore

1"The Economic Planning Agency (1988) provides the national capltal stock of the private sector by Industry. Long-tera real interest rates are frow Hamao and Ibbotson (1989).

"Data on value added by Industry are fron varlous Issues of the Annual Report on the National Accounts while usable land area by prefecture are from the Japan statistical rearbook. 
appropriate depende upon the nature of agglomeration effects within and between prefectures. One possibllity is that trassportation and communications coste within a prefecture are very lov relative to those between prefectures. Thls would be the case, for example, if Individual prefectural boundaries tend to correspond to geographlcal barriers, such as mountaln ranges and rivers, or if transportation and communicetions aystems vere wuch thicker within prefectures than between them. In this case total prefectural value added would provide the better measure of prefectural activity. Another possibility is that prefectural boundarles have littlo bearing on the range of aggloweration effect, in which case the density of activity in the prefecture captures economies of agglomeration better than the total level.

In fact, as wo discuss belov, the two measures yleld similar estimates of the acale of external economies. The total value added measure provides somewhat better explanatory power and allows us to identify the role of distance much more precisely.

Prefectural Amenities

To capture other features that might affect productivity, ve Include the number of ports (PORTS) and Shinkansen (bullet train) atations in the prefecture. 20 Only the number of porte was significant, and resulte with the number of Shinkansen stations are not reported.

Hence for the two sectors $1-M, F$ wo estimated the oquation:

20 Data on the number of ports and Shlnkansen stations are from Asahl Nevspapers (1991). 


$$
\begin{aligned}
& \bar{\beta}_{\mathrm{TI}}\left[\ln P_{\mathrm{pt}}+\ln \left(\mu_{\mathrm{r}} \mathrm{D}_{\mathrm{pr}}+\mu_{t} D_{t}\right)\right]+\bar{\beta}_{\mathrm{LI}} \ln W_{\mathrm{pt}}= \\
& \omega_{0}+\int_{j-1}^{46} \frac{Y_{11}}{\left(1+\delta d_{P J}\right)^{2}}+\kappa \text { PORTS }_{P}+\omega_{t} D_{t}+\omega_{r} D_{P r}+v_{P t}
\end{aligned}
$$

Jointly with equation (E1) to determine $\mu_{t}, \mu_{d}, \omega_{0}, \omega_{t}, \omega_{d}, \phi, \delta$, and $x$. We also estimated the equations without the reglonal dummies in the cost equation.

A potential source of almultanelty blas is that unobserved prefecture characteristics that onhance productivity in the prefecture may simultaneously ralse value added in that and In nearby prefectures and ralse the cost of labor and land In that prefecture. To correct for possible simultanefty blas we also estimated equations (E1) and (E2) using Instrumental varlables for the torm $A_{\text {lpt }}$. Instruments were the amount of land in the prefecture designated ag "capable of development", average temperature, and the average number of days of sunshine per year. ${ }^{21}$ Our Instrumental varlables appear to have better explanatory power for manufacturing than for finance, and for total value added than for density. Since manufacturing is the larger sector for all of the prefectures we consider, there 18 also more reason to think that amultanelty blas is greater in this sector. For these reasons we place more welght on the Instrumented (IV) equations in the case of manufacturing and on the uninstrumented (non-IV) equations in the case of finance, although we report all sets of results.

We estimated all specifications with the Full-Information Maximum-Llkelthood Tochnlque In TSP. Because of the very nonlinear nature of the estimation, we estimated each system of equations for given values of $\delta$ between 0 and 1 . We report the estimate that maximized the $\log 11$ kelihood function. The reported standard errors for other coefficlents, calculated by

2 Data on average temperature and on the average number of days of sunshine are from Asahl newspapers (1991). 
the Berndt-Hall-Hall-Hausman method, are thus conditional on the Indicated value of 6 being the true value.

When density cerves as the Industry ocale variable, the likelihood function as a function of $\delta$ is very flat. The value of $\delta$ that maximized the log likelihood was consequently vary unstable, and eensitive to the use of Instrumental variables. The Implied national agglomeration effects at the national level are simllar to those wo obtaln when wo use the level of ectivity. For these reasons our discussion focuses mostly on the results in which total value added rather than its density serves as the messure of prefectural activity.

4. Results

Appendix A reports the basic estimation results. Wo discuss four aspects In turn: (1) the effect of distance, or the range of agglomeration effects, (2) the elasticlty of productivity with respect to agglomeration at the local and national levels, (3) the magnitude of agglomeration effects across prefectures and Industries, and (4) the contribution of Increased agglomeration to productivity growth both to individual prefectures and nationally.

Distence

Table 3 reports, in 1 ts third column, the coefficlent $\delta$ on distance in the agglomeration term for the varlous cases. A value of zero lmplies that agglomeration effects are nationwlde, corresponding to aggregate external economies of scale, whlle an Infinite value means that agglomeration effects 
$-16-$

are purely local. Except for the case of finance with IV correction, the estimated distance coefficlent $\delta 1 \% 0.06$ or 0.07 for both manufacturing and finance. The coefficient on distance in finance with IV correction is .03. Table 4 reports the 1mplication of these estimates for the gradient of the agglomeration offect. In fact, the range of estimates of $\delta$ impiy a quite similar, and falriy steep, gradient. Moving activity a kilometer away from a location reduces its contribution to productivity at that location by between 87 and 94 per cent of 1 ts Impact in the 1mediate vicinity, while moving it away 10 kilometers raduces 1 ts lopact to between 39 and 57 per cent. Moving activity 100 kilometer. away dilutes ite lmpact to only 2 to 6 per cent of 1te local Impact. 22

We conclude, then, that agglomeration effects are substantially local in character. Nevertheloss, this range of estiates leaves room for aubstantial productivity spillovers across prefectures, as we now discuss.

Profectural and Natlonal Agglomeration Elastlclties

Since the magnitude of the parameter depends on units in whlch value added 1s measured, we find it more inetructive to report the elasticity of the effect of activity on productivity loplied by our estimates of and $\delta$. Our apecification Implies that this elasticity declines ag the overall measure of nearby activity Increases, however, so that the effect can vary substantially from prefecture to prefecture. Hence we calculate the elasticities implled by our ostimates for each prefecture at the average value of the agglomeration

23then density rather than the level of value added served as the activity indicator, our estimate of $\delta$ was very sensitive to IV correction. Without correction the estimate was very high, lmplying virtually no splliovers beyond the Immediate vicinity, whlle with the correction the Implied spillovers were national. 
variable during the period of estimation. Tablo 5 reports the calculated - lesticities prefecture by prefocture. Note that they vary widely, and are abstantially lower in large profectures. Table 3 reports the aluple average of the prefectural elasticities.

We report elasticities of two types. One we call the local elasticity, which is the percentage increase in productivity at a location resulting from - one per cent increage in activity at that location holding activity - Inewhere constant. We also calculate the national elasticity for each prefecture, which is the percentage effect on productivity in that prefecture of a one per cent increase in activity in all profoctures.

The presence of reglonal dumbies in the cost equations tends to reduce the size of the elasticitios by between 3 to 8 per cent. Thin reduction is not surprising since the 10 regional dumies eliminate the contribution of crosa-regional variability to the estimation.

Instrumental variables correction reduces the estimated elasticities for finance when total value added measures activity, and for both industries when density measures activity. This direction is expected aince unobserved prefectural characteristics that ralse productivity in a prefecture will also ralse factor cost in the prefecture. Surprisingly, IV correction actually ralses the estimated elastlcltiea alightly in manufacturing when total value added measures activity.

Without IV correction, both the local and national elasticities in finance exceed those in manufacturing by 3 to 8 percentage points. Since instrumental variables correction reduces the estimated elasticities for finance considerably, and slightly raises those for manufacturing, instrumentel variables correction reveraes the ordering between the two industries. Since finance is a smaller share of prefectural GDP than is 
manufacturing for all prefectures, thore 1s less scope for simultanelty blas In finance. Moreover, our Instruments explain manufacturing GDP more successfully than they explain financlal GDP. For this reason we concentrate more on the IV corrected equation in menufacturing and the uncorrected -quations in finance.

The elasticities Indicate that externalities for both industrles are largely local. With total value added measuring activity, estimates of local - lasticlties range from 9 to 20 per cent, with the natlonnl elasticlty a quarter to half as much higher.

It 1s useful to compare our results on the regional scope of externalities with Caballero and Lyons' (1992) finding about the1r eectoral acope. Their study finds that, within U.S. manufacturing, external effects are mall within sectors but substantial across manufacturing as a whole. In contrast, we find strong externalitles within reglons but less between them. Together, our results suggest that location rather than specialization is a wuch greater source of external effects.

The Exhaustion of Aggloweration Externalities

Table 6 reports the contribution of total agglomeration economles in each Industry in each prefecture, 1.e. the value of term $\exp \left(-\phi / A_{1 p}\right)$ where $A_{1 p}$ is given in equation 1 , at the beglnning and at the end of the sample. We report these for the case in which reglonsl dumieg are included in (E2), using the IV-corrected measure of manufacturing activity and the non-IV corrected measure of financial activity.

The aglomeration measure $\exp \left(-\phi / A_{1 p}\right)$ has a theoretical maximum of 1 . Note that the measure for some prefectures is within one or two percentage 
pointe of this maximum, Indicating that the potential for agglomeration economies ia nearly exhausted.

For manufacturing. Tokyo and Alchl (Nagoya) prefectures report the largest aggloweration extermalities in 1990, both above .99. At the other extreme, Aomorl prefecture In northern Honshu and Nagasak1 prefecture in Kyushu have the lowest manufacturing extermalities in 1990, at about 75 and 77 per cent of the theoretical maximun, respectivoly. These figures imply that the low level of manufacturing in and around this second pair of prefectures lowered productivity there to 11tele over three-fourthe of what it is in the first pair.

In finance, the largest agglomeration effects appear again for Tokyo now followed by Kanagawa (Yokohame). MyazakI prefecture in Kyushu, and then Akita prefecture In Northem Honshu, report the lowest level of agglomeration externalities.

Relative agglomeration effects also contribute to the comparative advantage of prefectures between manufacturing and finance. In Chiba and Hokkaido, for example, the contribution of agglomeration to productivity is about the same in manufacturing and finance, but in prefectures like Alchl and Shiga, the contribution of aggloweration to productivity is about 3 per cent higher in manufacturing than it is in finance.

Moreover, the contribution of agglomeration economles to comparative advantage has shifted over time. Over the entire perlod externalities in finance have grown by about three per cent in Kanagawa and only by one per cent in manufacturing. In Aomorl prefecture, however, manufacturing externalitios grew by about 9 per cent in, menufacturing, but only by about 5 per cent In finance.

Our functional form forces the contribution of agglomeration to 
productivity to diminish with the agglomeration parameter $A_{p}$. To test whether or not a diminishing agglomeration offect 1s Implled by the data, we estimated the model using the following variant of the production function (2):

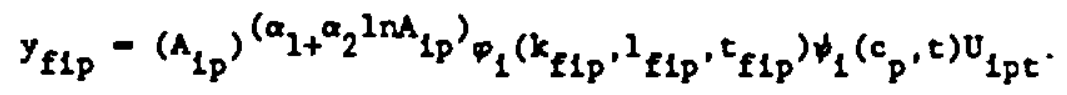

Th1s epecification allows the agglomeration elasticity afther to incresse $\left(a_{2}>0\right)$ or to decrease $\left(a_{2}<0\right)$, and encompasges the special case of a constant elasticlty of productivity with respect to agglomeration $\left(\alpha_{2}-0\right)$ assumed, for example, by Clccone and Hall (1993). For most values of $\delta$, we obtalned significantly positive estinntes of $a_{1}$ and elgnificantly negative astimates of $a_{2}$. For all values of $\delta$ that we considered, the estimated coefficients imply an average agglomeration elasticity for Japan as a whole simllar to what we report here, and negative agglomeration elasticitles for the largest prefectures.

Agglomeration and Grovth

Table 6 also reports the growth in the agglomeration measure during the ample perlod for each prefecture. The GDP-welghted natlonal average growth In the manufacturing agglomeration measure is .17 per cent whlle the growth in the finance aglomeration measure is .26 per cent. These measures compare with an overall growth in output per vorker of 3.0 per cent in manufacturing and 2.9 per cent in finance. Hence, agglomeration effects can account for a amall but nontrivial part of overall growth in per caplta output in these eectors. 
5. Conclusion

Th1s paper has used data on land prices and wages in the Japanese prefectures to Infer the extent and range of agglomeration economies in manufacturing and in financial services. The main Implications are that: whlle the extent of agglomeration economies in both sectors I. 1 gnificant (with agglomeration elasticlties of around 10 per cent or more), they are falrly locallzed geographically. (2) Lese conclusively we find agglomeration economles to bo larger in finance than in manufacturing. (3) Agglomeration economles appear to be nearly exhausted in the prefectures where they are most pronounced. (4) The lowest observed measures of agglomeration economles Imply productivity levels that are about three-quarters of the highest observed agglomeration economies. The exploitation of agglomeration economien can explain about 5.6 per cent of the labor productivity growth in manufacturing and 8.9 per cent of labor productivity growth in finance during the perlod of our sample.

These resulta suggest an explanation for the Increased concentration of land prices In Japan based on the growth of the financlal service sector. If financlal services tend to occupy localities with larger land areas, elther because of historical accldent or beceuse agglomeration effects are more pronounced in these ectors, then an Increase in the relative price of these services in termg of manufactures w11 act to Increase relative land prices in lerger areas. Of the ten reglons in Table Al, the Greater Tokyo region has the largest area of land that could be used for bullding purposes, followed by the Kinkl area.2: As a consequence of higher land prices in these areas, and

\footnotetext{
2 other reglons such as Hokkaldo and Hokuriku have higher total land areas, but most of this land is mountalnous, forested, or agrlcultural and hence not avaliable for private development. Within the Tokyo region, even the
} 
of higher wages that workers must therefore be pald to compensate them for the higher cost of living in these areas, manufacturing activity will shift toward smaller areas. The net effect on total prefectural output may be relatively .mall. area than any others except Hokkaldo and Aich1. 


\section{REFERENCES}

Arnott, R1chard (1979), "Optimum Clty S1ze In a Spatial Economy," Journal of Orban Economice, 6: 65-89.

Arrow, Kenneth J. (1962), "The Economlc Implicationg of Learning by Doing." Revieu of Economic studies, 29: 155-173.

Asah1 Newspapers (1991), MLnryoku (Tokyo: Asah1 Newspapers).

Boone, Peter (1989), "HIgh Land Valuea in Japan: Is the Archipelago Worth Eleven Trillion Dollars?" Draft, Harvard University.

Caballero, R1cardo J. and R1chard $\mathrm{K}$. Lyons (1992), Externsi Effects in U.S. Procyclicsl Productivity." Journal of Monetary Economics, 29: 209-226.

Chenery, Holl1s B. and Molses Syrquin (1975), Patterns of Development: 1950-1970 (London: Oxford University Press).

Clccone, Antonlo and Robert z. Hall (1993). "Productivity and the Density of Econom1c Activity," NBER Working Paper Mo, 1313.

Deardorff, Alan v. (1984), Testing Trade Theorles and Predicting Trade Flows," Bandbook of International sconomles, Volume I, edited by Ronald $H$. Jones and Peter B. Kenen (Amsterdas: Elsevler Sclence Publlshers). 
Dlxit, Avinash and Joseph E. StIglltz (1977). Monopolistlc Competition and Optimum Product Diversity," American scosomic Reviov, 72: 389.

Economlc Planning Agency, Government of Jepan (1988), Grose Capltal stock of Private Enterprien (Tokyo)

Economlc Planning Agency, Government of Japan (Varlous yearg), Annual Roport on Prefectural Accounti' (Tokyo).

Econoulc Planning Agency, Government of Japan (Varlous years), Annual Report on Natlonal Account. (Tokyo).

Fuj1ta, Masahisa (1989), Orban Economle thoory: Land Oso and Clty sizo (Cambridge: Cambridge University Pross).

Glaeser, Edward L., Hed1 D. Kallal, Joge A. Schelnkonan, and Andrel Shletfer (1992), "Growth In Citles," Journal of Pol1tical Economy, 100: 1126-1152.

Hamao, Yasushl and Roger Ibbotson (1989), stocks, Bonds, and Inflatton: Japan (Chicago: Ibbotson Associates).

Helpman, Elhanan (1984), -Increasing Returns, Imperfect Markets, and Trade Theory," Bandbook of International sconomies, volume I, edited by Ronald $H$. Jones and Peter B. Kenen (Amsterdan: Elsevler Sclence Publishers). 
Helpman, Elhanan and David PInes (1980), Optimal Public Investment and Dispersion Pollcy In a System of Open Clties," American Economic Review, 70: $507-514$.

Henderson, J. Vernon (1987), "General Equillbrlum Modeling of a System of Cltles," gandbook of Reglonal and Orban Economios, Volume II, odited by E.S. Mills (Amsterdam: Elsevier Sclence Publishers).

Henderson, J. Vernon (1988), Orban Development, Theory, Fact, and Illuglon (New York: Oxford University Press).

Henderson, J. Vernon (1994), "Extermalltles and Industrlal Development," KBER Working Paper Wo. 1730

Jacobs, Jane (1969), The Economy of Clt1es. (New York: Random House).

Jacobs, Jane (1984), Clties and the Wealth of Nations. (New York: Random House).

Kuzneta, Simon (1966), Kodern Economic Growthe Rate, structure, and spread (New Haven: Yale University Press).

Lucas, Robert E. (1988), "On the Mechenics of Economic Development," Journal of Monetary Economica, 21: 3-42.

M111s, Edwin S. (1967), "An Aggregative Model of Resource Allocation in a Metropolltan Area," American Economic Roview, S7: 197-210. 
Rauch, James E. (1993), "Productivity Gaina from Geographic Concentration of Humsn Capital: Evidence from the C1t1es," Journal of Orban Economice, 34 : $380-400$.

Romer, Paul (2986), "Increasing Returns and Long-Run Growth," Journal of Pol1t1cal sconomy, 94: 1002-1037.

Sassen, Saskle (1991), The Globel city. (Princeton: Princeton Univeralty Press). 
-27 .

Table 1

Gros: Prefectural Product: Privato Sector Industrles

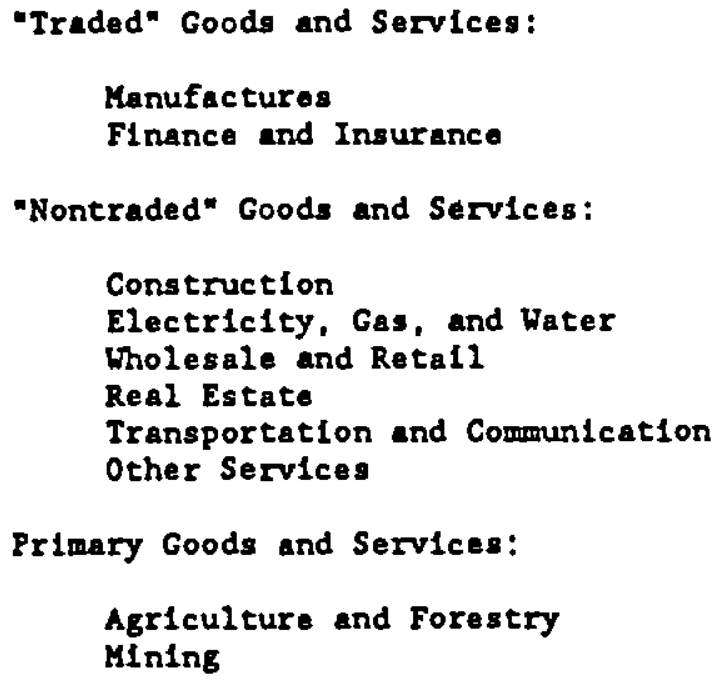

"Traded" Goods and Services:

Manufactures

FInance and Insurance

"Nontraded" Goods and Services:

Construction

Electriclty, Gas, and Water

Wholesale and Retall

Real Estate

Iransportation and Communlcation

Other Services

Primary Goods and Services:

Agriculture and Forestry

Mining

Table 2

Parameter Estimates

$\beta_{\text {LM }}$ Direct and Indirect labor share in manufacturing value added .72

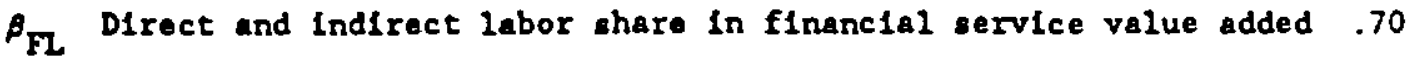

$\beta_{\text {TI }}$ Direct and 1ndirect land share in manufacturing value added .12

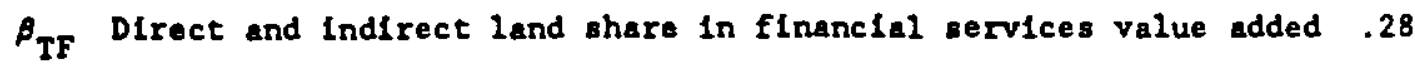

Valuations are In bl111ons of 1980 yen, digtances are measured in kllometer: and areas in equare kilometers. 
TABLE 3:

AVERAGE ELASTICITIES AND DISTANCE COEFFICIENTS

TOIAL VALUE ADOED

SINGLE EQUATION

WITHOUT REGIONAL DUMMIES

WITH REGIONAL DUMMIES

INSTRUMENTAL VARIABLES

WITHOUT REGIONAL DUMMIES

WITH REGIONAL DUMMIES

SINGLE EQUATION

WITHOUT REGIONAL DUMMIES

WITH REGIONAL DUMMIES

INSTRUMENTAL VARIABLES

WITHOUT REGIONAL DUMMIES

WITH REGIONAL DUMMIES

DENSITY OF VALUE ADDED

WITH REGIONAL DUMMIES

SINGLE EQUATION

INSTRUMENTAL VARIABLES

WITH REGIONAL DUMMIES

SINGLE EQUATION

INSTRUMENTAL VARIABLES

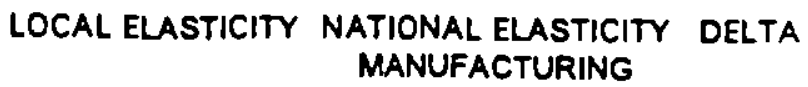

0.133

$0.159 \quad 0.07$

$0.12 \quad 0.08$

0.152

0.101

$0.177 \quad 0.07$

$0.12 \quad 0.07$

FINANCE

0.199

0.136

0.244

0.167

0.08

0.08

0.12

0.091

0.20 .03

$0.149 \quad 0.03$

MANUFACTURING

0.15

0.02

$0.15 \quad 0.5$

$\begin{array}{ll}0.18 & 0.005\end{array}$

FINANCE

0.25

$0.25 \quad 0.45$

0.01

$0.14 \quad 0.001$

TABLE 4: AGGLOMERATION GRADIENTS

$\begin{array}{rrr}\text { DELTA } & \text { DISTANCE } & \text { GRADIENT } \\ 0.03 & 1 & 0.84 \\ 0.03 & 10 & 0.59 \\ 0.03 & 100 & 0.06 \\ 0.08 & 1 & 0.89 \\ 0.06 & 10 & 0.39 \\ 0.08 & 100 & 0.02 \\ 0.07 & 1 & 0.87 \\ 0.07 & 10 & 0.35 \\ 0.07 & 100 & 0.02\end{array}$


TABLE 5: AGGLOMERATION ELASTICITIES

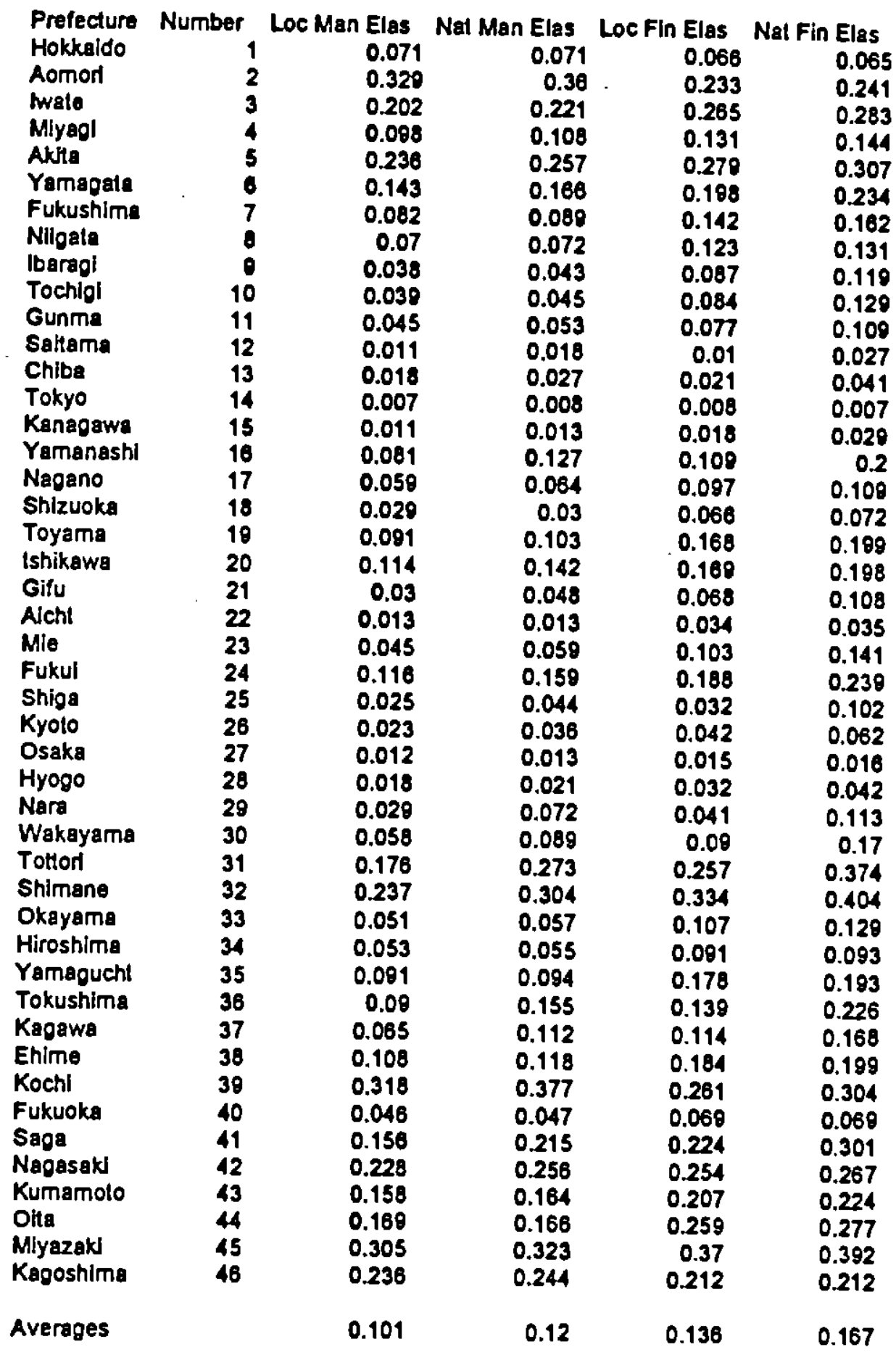


TABLE 6: AGGLOMERATION COEFFICIENTS AND GROWTH

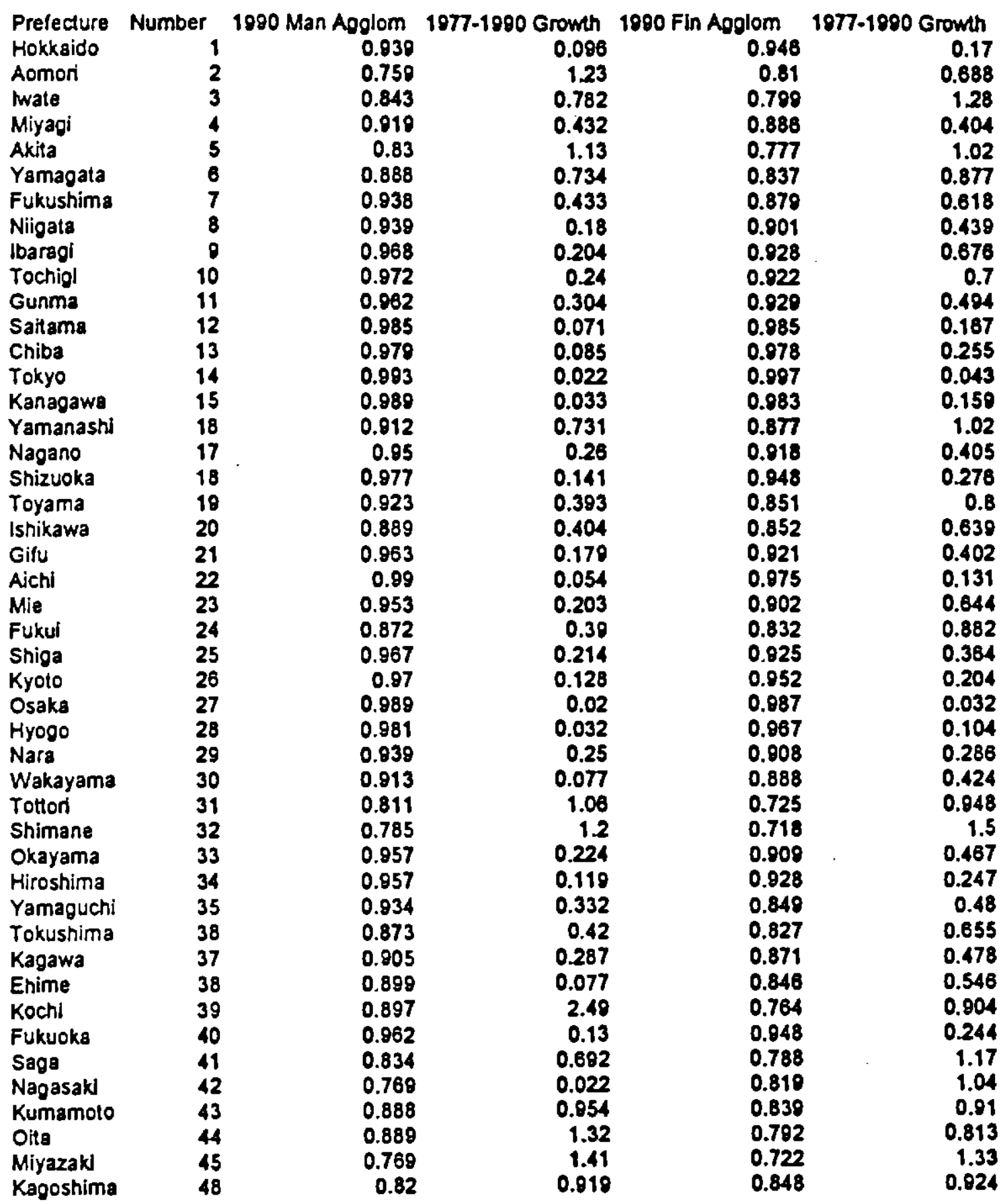


TABLE A1: REGIONAL ASSIGNMENTS OF THE PREFECTURES

1 HOKKAIDO
Hokkaido
2 TOHOKU
Aomori
Iwate
Miyagi
Akita
Yamagata
Fukushima
3 HOKURIKU
Niigata
Toyama
Ishikawa
Fukui
4 KANTO
Ibaragl
Tochigi
Gunma
Yamanashi
Nagano
5 TOKYO
Chiba
Tokyo
Kanagawa
Saitama
6 TOKAl
Shizuoka
Gifu
Aichi
Mie

\author{
7 KINKI \\ Shiga \\ Kyoto \\ Osaka \\ Hyogo \\ Nare \\ Wakayama \\ - CHUGOKU \\ Tottori \\ Shimane \\ Okayama \\ Hiroshima \\ Yamaguchi \\ $\theta$ SHIKOKU \\ Tukushima \\ Kagawa \\ Ehime \\ Kochl \\ 10 KYUSHU \\ Fukuoka \\ Saga \\ Nagasak| \\ Kumamoto \\ Oita \\ Miyazaki \\ Kagashima
}

Mie 
APPENDIX A

ESTIMATION RESULTS

Varlable Deflnitions

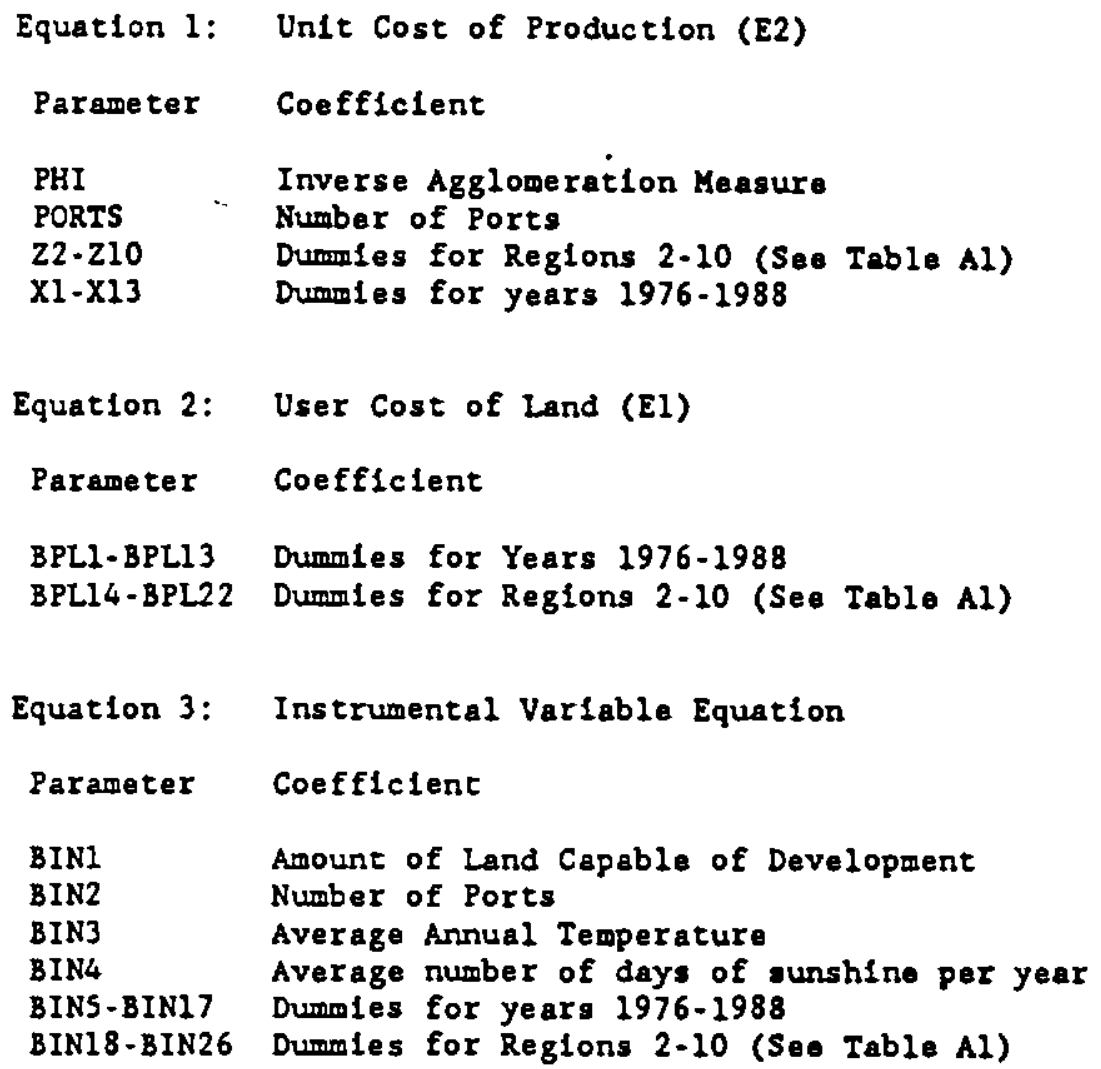

All speciflcations were estlmated by the Full-Information Maximun-Likelihood routine In TSP. Reported equations are for the value of distance deflator delta that maximizes the log likelihood function. Standard errora are calculated by the Berndt-hall-hall-hausman mathod, and are conditional on the reported estlmate of delta being the true value. 
MANUFACTURING 1

(value added, no IV's, no Reglonal Dummles) NUMBER OF OBSERVATIONS - 598

$\begin{array}{ll}\text { Parameter } & \text { Estlmate } \\ \text { PHI } & -124.197 \\ \text { PORTS } & .203389 \\ \text { X1 } & -4.51051 \\ \text { X2 } & -4.57924 \\ \text { X3 } & -4.66484 \\ \text { X4 } & -4.59954 \\ \text { X5 } & -4.51357 \\ \text { X6 } & -4.44328 \\ \text { X7 } & -4.22626 \\ \text { X8 } & .4 .09467 \\ \text { X9 } & -4.06904 \\ \text { X10 } & .4 .01311 \\ \text { X11 } & -3.97258 \\ \text { X12 } & -4.03143 \\ \text { X13 } & -3.95837 \\ \text { BPL1 } & .126496 \\ \text { BPL2 } & .050971 \\ \text { BPL3 } & .021273 \\ \text { BPL4 } & .020859 \\ \text { BPL5 } & .020500 \\ \text { BPL6 } & .020502 \\ \text { BPL7 } & .051284 \\ \text { BPL8 } & .113081 \\ \text { BPL9 } & .108012 \\ \text { BPL10 } & .126672 \\ \text { BPL11 } & .125637 \\ \text { BPL12 } & .060582 \\ \text { BPL13 } & .070645 \\ \text { BPL14 } & .014801 \\ \text { BPL15 } & .024372 \\ \text { BPL16 } & -.983557 E-02 \\ \text { BPL17 } & -.017687 \\ \text { BPL18 } & -.893958 E-03 \\ \text { BPL19 } & -.013207 \\ \text { BPL20 } & -.746828 E-02 \\ \text { BPL21 } & -.443974 E-02 \\ \text { BPL22 } & -.908986 E-02\end{array}$

$\begin{array}{ll}\text { Standsrd } & \\ \text { Error } & t-g t a t 1 s t 1 c \\ 6.47492 & -19.1812 \\ .021130 & 9.62565 \\ .029520 & -152.796 \\ .040385 & -113.391 \\ .050076 & -93.1550 \\ .054460 & -84.4575 \\ .056534 & -79.8378 \\ .053083 & -83.7038 \\ .065272 & -64.7486 \\ .053654 & -76.3163 \\ .038302 & -106.235 \\ .038260 & -104.890 \\ .035457 & -112.041 \\ .038590 & -104.468 \\ .033546 & -118.000 \\ .034018 & 3.71854 \\ .034003 & 1.49900 \\ .032248 & .659686 \\ .032255 & .646689 \\ .032261 & .635464 \\ .032237 & .635983 \\ .039544 & 1.29690 \\ .061138 & 1.84960 \\ .041405 & 2.60868 \\ .040799 & 3.10479 \\ .035046 & 3.58494 \\ .032628 & 1.85674 \\ .033718 & 2.09514 \\ .033129 & .446756 \\ .034068 & .715393 \\ .032344 & -.304088 \\ .032087 & -.551211 \\ .032529 & -.027482 \\ .032017 & -.412503 \\ .032462 & -.230060 \\ .032241 & -.137705 \\ .031986 & -.284185 \\ & \end{array}$

1 2

CSSR

12.43811

3.90043

QLOGL -967.256

DELIA $=0.070000$ 


\section{MANUFACTURING 2}

(value added, no IV's, wh Reglonal Dummles) NUMBER OF OBSERVATIONS - 598

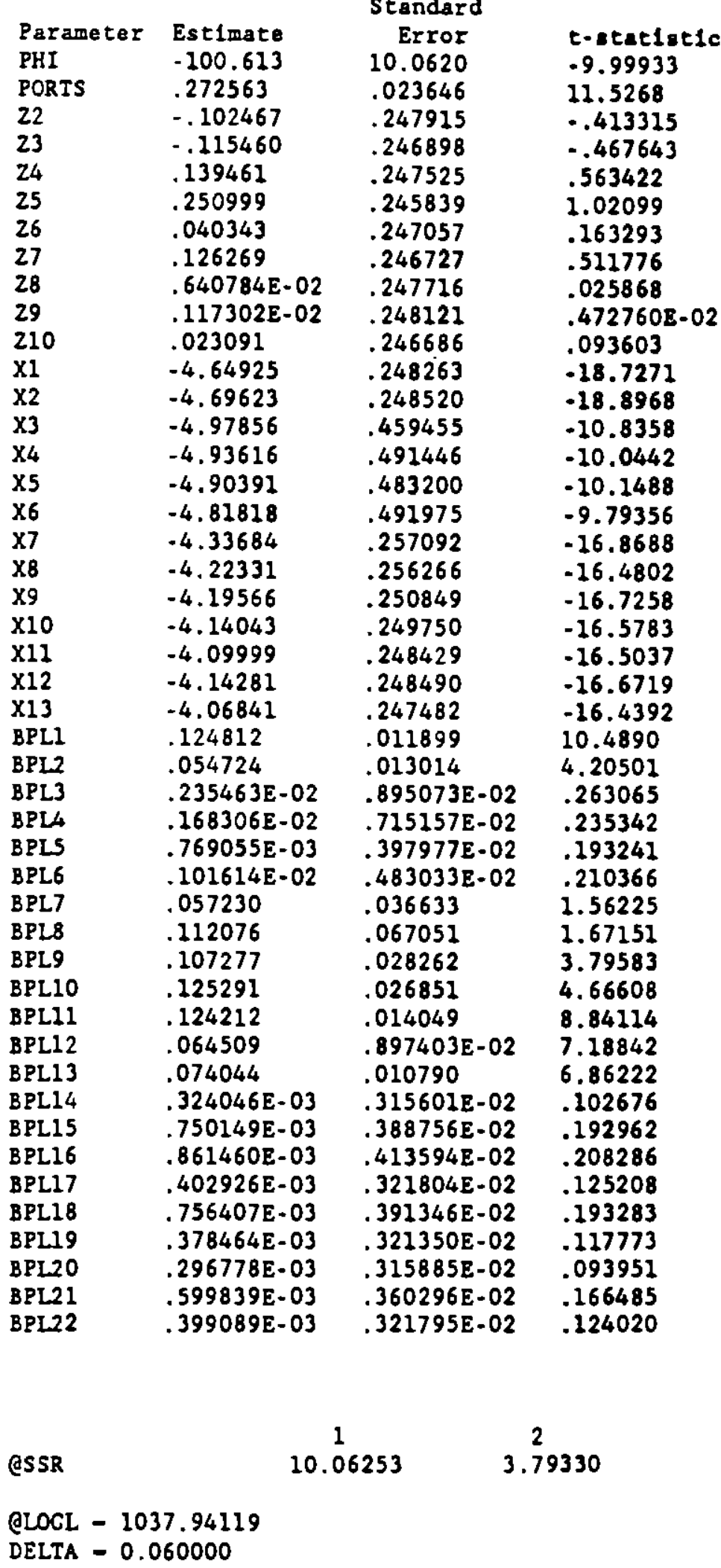




\section{MANUFACTURING 3}

(value added, with IV'a, no Reglonal Dummles) NUMBER OF OBSERVATIONS - 598

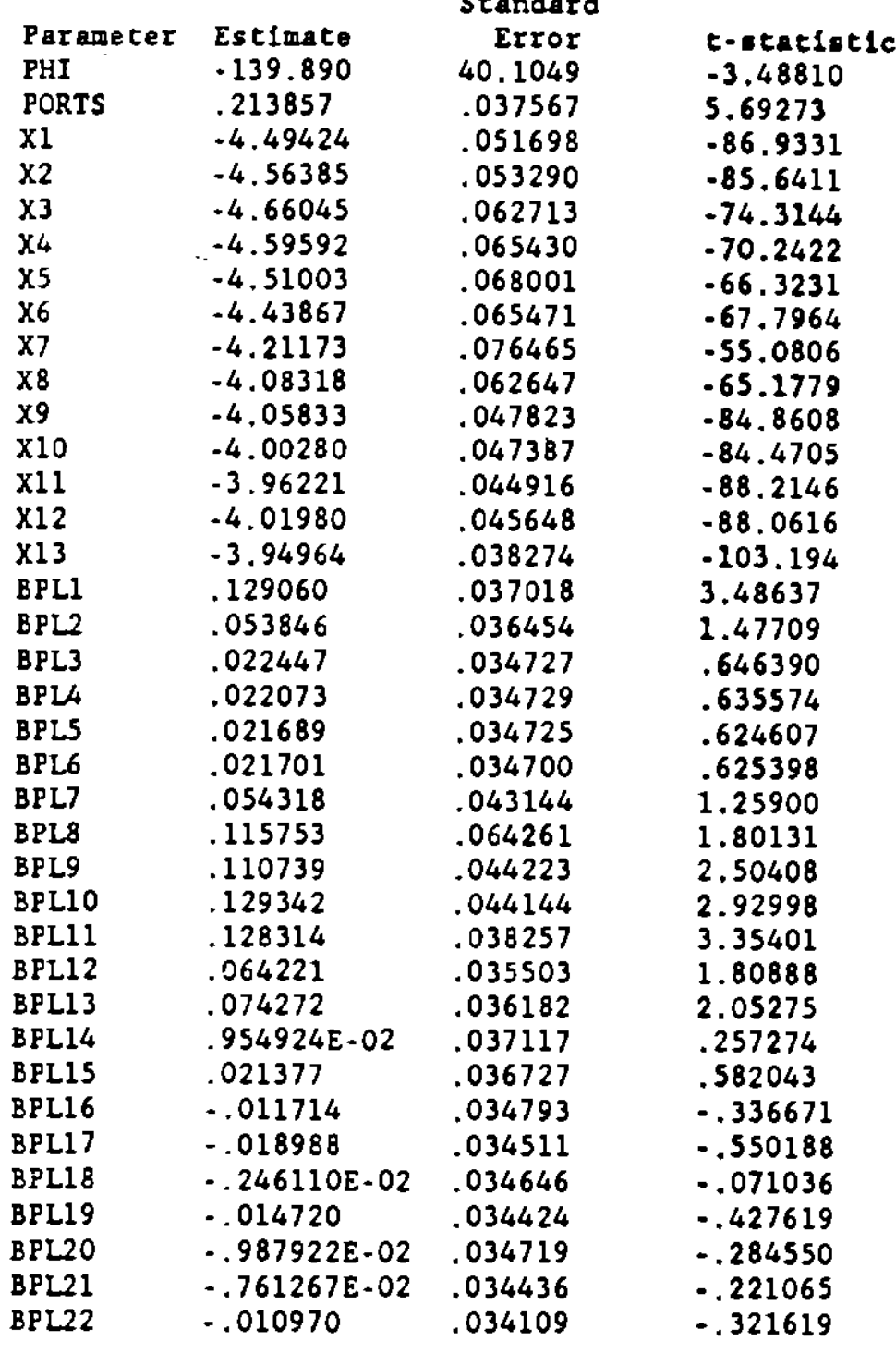


Instrumental Varfable Equation

$\begin{array}{llll}\text { BIN1 } & -.107082 E-06 & .414517 E-07 & -2.58329 \\ \text { BIN2 } & .996451 E-03 & .411794 E-03 & 2.41978 \\ \text { BIN3 } & . .149639 E-03 & .452713 E-04 & -3.30537 \\ \text { BIN4 } & .237044 E-06 & .461968 E-06 & .513117 \\ \text { BIN5 } & .270284 E-02 & .642480 E-03 & 4.20689 \\ \text { BIN6 } & .255305 E-02 & .638663 E-03 & 3.99749 \\ \text { BIN7 } & .246789 E-02 & .644902 E-03 & 3.82677 \\ \text { BIN8 } & .240897 E-02 & .653398 E-03 & 3.68684 \\ \text { BIN9 } & .245121 E-02 & .654170 E-03 & 3.74705 \\ \text { BIN10 } & .250518 E-02 & .649871 E-03 & 3.85489 \\ \text { BIN11 } & .247243 E-02 & .645981 E-03 & 3.82740 \\ \text { BIN12 } & .238829 E-02 & .651813 E-03 & 3.66407 \\ \text { BIN13 } & .233437 E-02 & .660507 E-03 & 3.53421 \\ \text { BIN14 } & .231689 E-02 & .661964 E-03 & 3.50003 \\ \text { BIN15 } & .232041 E-02 & .663377 E-03 & 3.49788 \\ \text { BIN16 } & .223909 E-02 & .674112 E-03 & 3.32154 \\ \text { BIN17 } & .208692 E-02 & .667406 E-03 & 3.12692\end{array}$

$\begin{array}{lccc} & 1 & 2 & 3 \\ \text { ESSR } & 12.62479 & 3.88510 & 0.00058590 \\ \text { QLOGL }-4256.51651 & & & \\ \text { DELTA }-0.070000 & & & \end{array}$


KANUFACTURING 4

(value added, with IV', with regional dummies) NUMBER OF OBSERVATIONS - 598

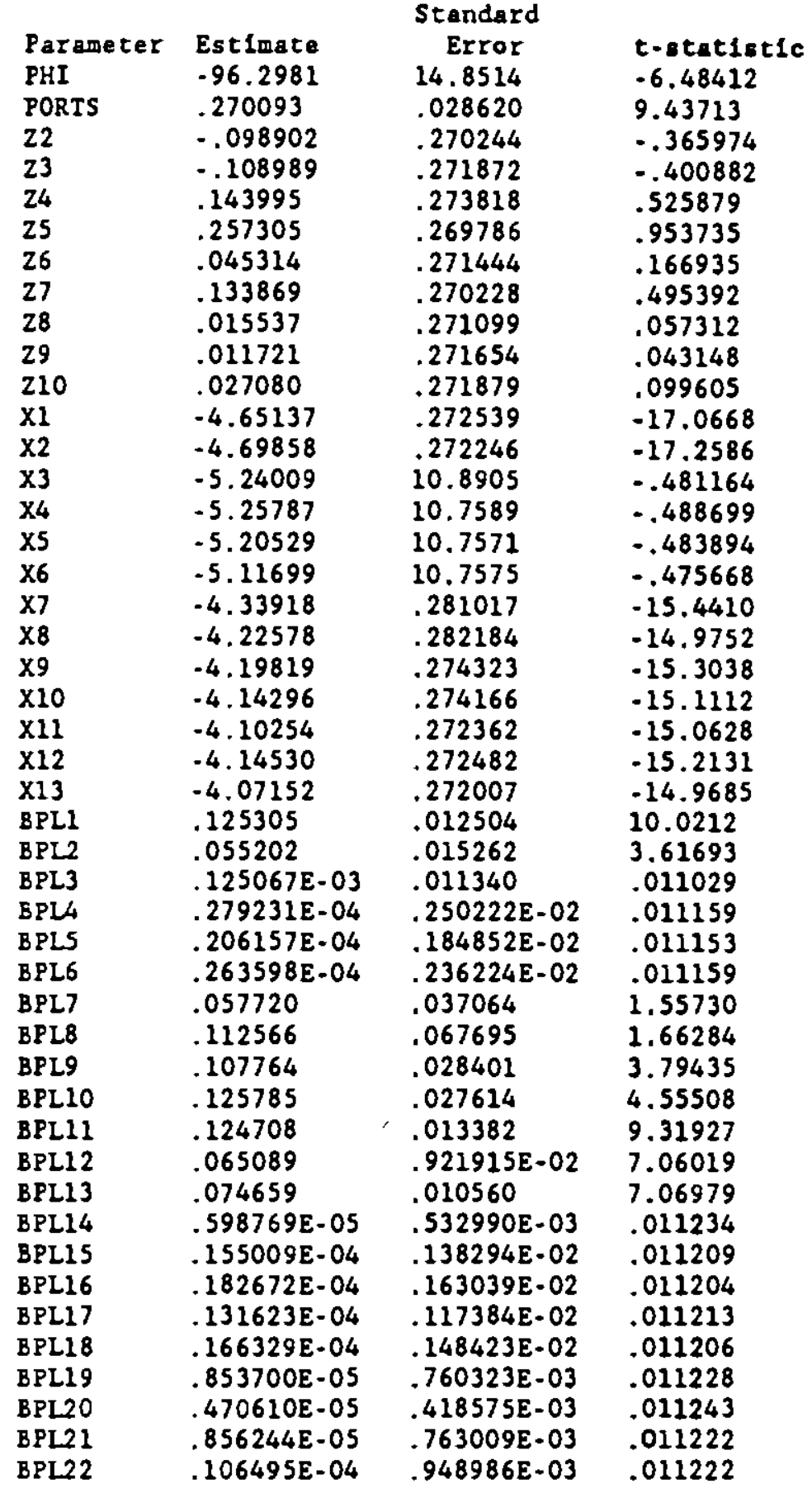


Instrumental Varlable Equation

$\begin{array}{llll}\text { BIN1 } & .116084 E-04 & .109399 E-05 & 10.6111 \\ \text { BIN2 } & . .014987 & .322964 \mathrm{E}-02 & -4.64046 \\ \text { BIN3 } & .011256 & .117057 \mathrm{E}-02 & 9.61558 \\ \text { BIN4 } & . .774294 \mathrm{E}-04 & .738653 \mathrm{E}-05 & -10.4825 \\ \text { BIN5 } & . .183145 & .029263 & -6.25860 \\ \text { BIN6 } & -.183107 & .029249 & -6.26036 \\ \text { BIN7 } & -.179399 & .029101 & -6.16467 \\ \text { BIN8 } & -.179062 & .029012 & -6.17211 \\ \text { BIN9 } & -.174639 & .028829 & -6.05775 \\ \text { BIN10 } & -.176477 & .028904 & -6.10554 \\ \text { BIN11 } & -.183282 & .029353 & -6.24403 \\ \text { BIN12 } & . .183474 & .029345 & -6.25221 \\ \text { BIN13 } & -.183528 & .029371 & -6.24859 \\ \text { BIN14 } & -.183552 & .029356 & -6.25253 \\ \text { BIN15 } & . .183537 & .029361 & -6.25109 \\ \text { BIN16 } & . .183683 & .029365 & .6 .25521 \\ \text { BIN17 } & -.184088 & .029341 & -6.27427 \\ \text { BIN18 } & .159675 & .021755 & 7.33966 \\ \text { BIN19 } & .141469 & .022313 & 6.34029 \\ \text { BIN20 } & .165408 & .022065 & 7.49642 \\ \text { BIN21 } & .160859 & .022136 & 7.26674 \\ \text { BIN22 } & .153100 & .022680 & 6.75038 \\ \text { BIN23 } & .153702 & .023092 & 6.65602 \\ \text { BIN24 } & .152045 & .023091 & 6.58457 \\ \text { BIN25 } & .162392 & .023970 & 6.77493 \\ \text { BIN26 } & .144142 & .022650 & 6.36402 \\ & & & \end{array}$

$\begin{array}{lccc} & 1 & 2 & 3 \\ \text { QSSR } & 14.75826 & 3.78608 & 0.086170 \\ \text { QLOGL }-2754.78006 & & & \\ \text { DELTA }-0.070000 & & & \end{array}$


MANUFACIURING 5

(densftieg, no IV'a, with reglonal dumies) NUMBER OF OBSERVATIONS - 598

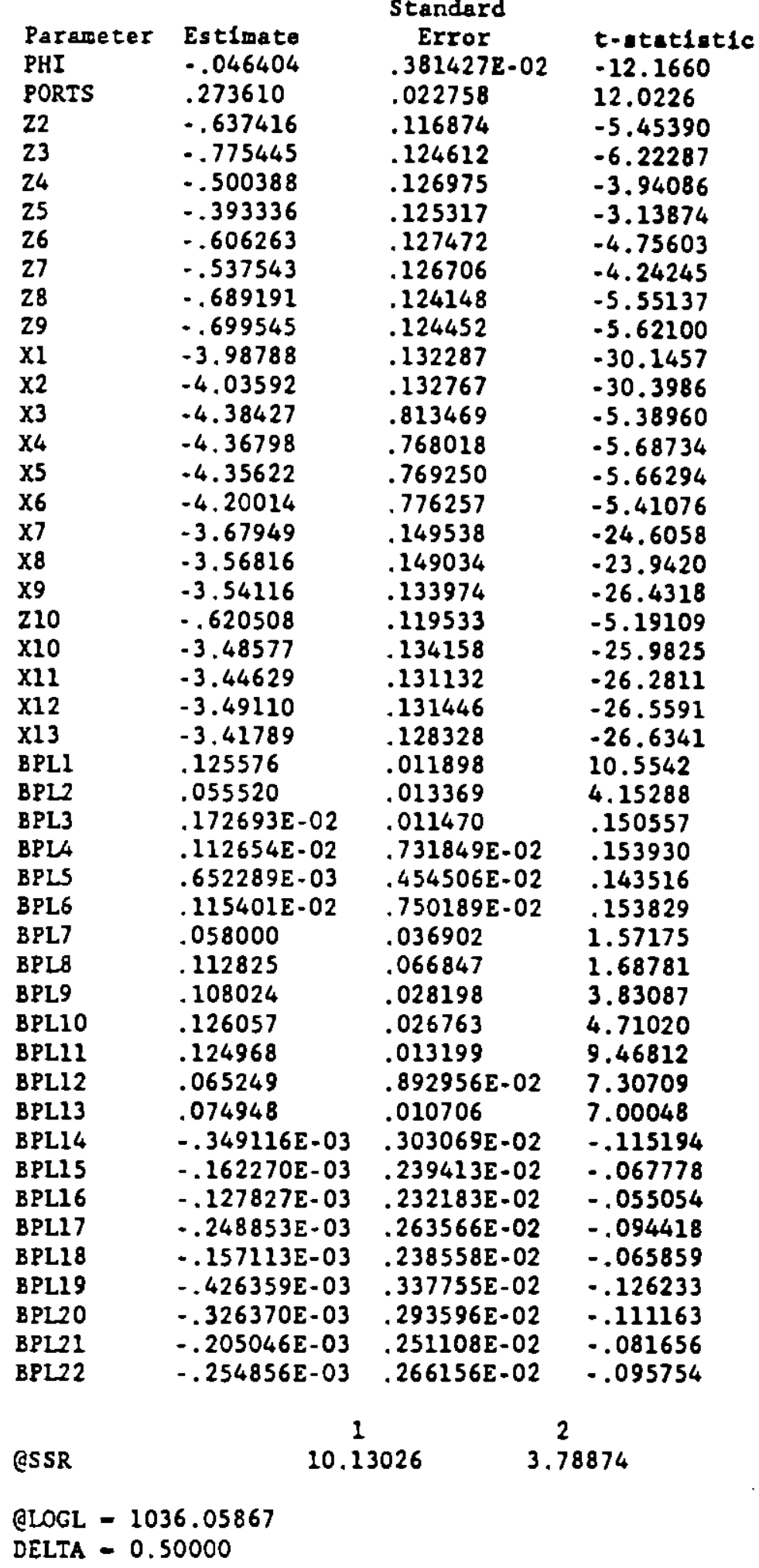


MANUFACIURING 6

(densities, with IV's, with regional dummies) NUMBER OF OBSERVATIONS - 598

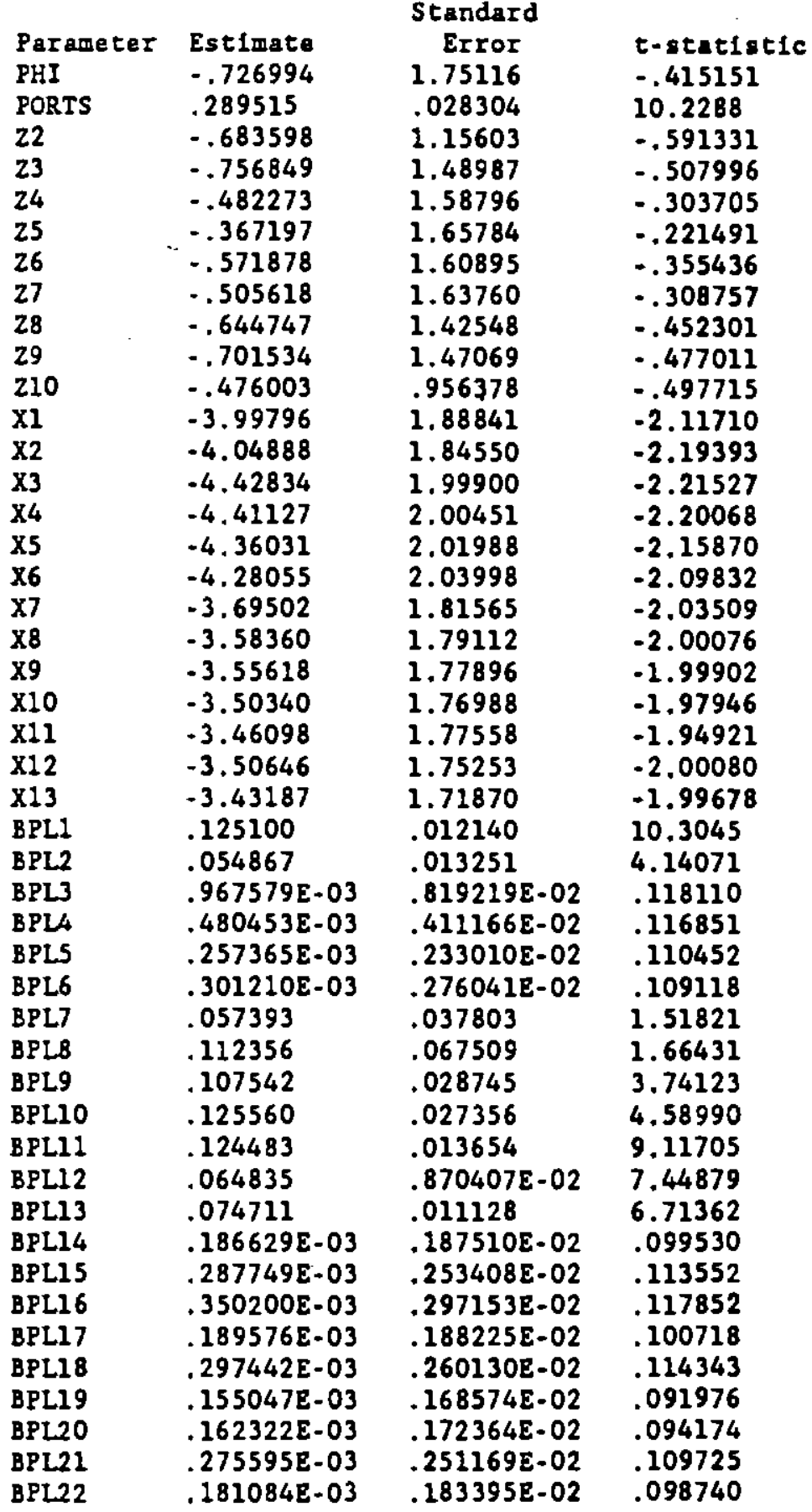


Instrumental Varlable Equation

$\begin{array}{llll}\text { BIN1 } & .523507 E-05 & .117057 \mathrm{E}-04 & .447225 \\ \text { BIN2 } & .743785 \mathrm{E}-03 & .051920 & .014325 \\ \text { BIN3 } & . .671814 \mathrm{E}-03 & .648847 \mathrm{E}-02 & -.103540 \\ \text { BIN4 } & . .257871 \mathrm{E}-04 & .614906 \mathrm{E}-04 & -.419367 \\ \text { BIN5 } & 1.00613 & .273087 & 3.68429 \\ \text { BIN6 } & .982102 & .273534 & 3.59042 \\ \text { BIN7 } & .962883 & .273132 & 3.52534 \\ \text { BIN8 } & .954838 & .273201 & 3.49500 \\ \text { BIN9 } & .962702 & .273132 & 3.52467 \\ \text { BIN10 } & .971731 & .273016 & 3.55925 \\ \text { BIN11 } & . .963852 & .273157 & 3.52856 \\ \text { BIN12 } & .949057 & .273034 & 3.47596 \\ \text { BIN13 } & .941717 & .273196 & 3.44704 \\ \text { BIN14 } & .935968 & .273170 & 3.42632 \\ \text { BIN15 } & .939189 & .273309 & 3.43636 \\ \text { BIN16 } & .925078 & .273329 & 3.38449 \\ \text { BIN17 } & .905282 & .273408 & 3.31110 \\ \text { BIN18 } & . .542689 & .237773 & -2.28238 \\ \text { BIN19 } & . .728995 & .249342 & -2.92367 \\ \text { BIN20 } & -.784601 & .263617 & -2.97629 \\ \text { BIN21 } & -.822427 & .267471 & -3.07483 \\ \text { BIN22 } & -.792753 & .265320 & -2.98791 \\ \text { BIN23 } & -.808511 & .274524 & -2.94513 \\ \text { BIN24 } & . .684071 & .267566 & -2.55664 \\ \text { BIN25 } & -.703303 & .272968 & -2.57650 \\ \text { BIN26 } & -.399443 & .265256 & -1.50588\end{array}$

GSSR

1

12.23521

2

3

QLOGL - 1647.97457

DELTA -0.0050000 
FINANCE 1

(vslue added, no IV's, no Reglonal Dummles) NUMBER OF OBSERVATIONS - 598

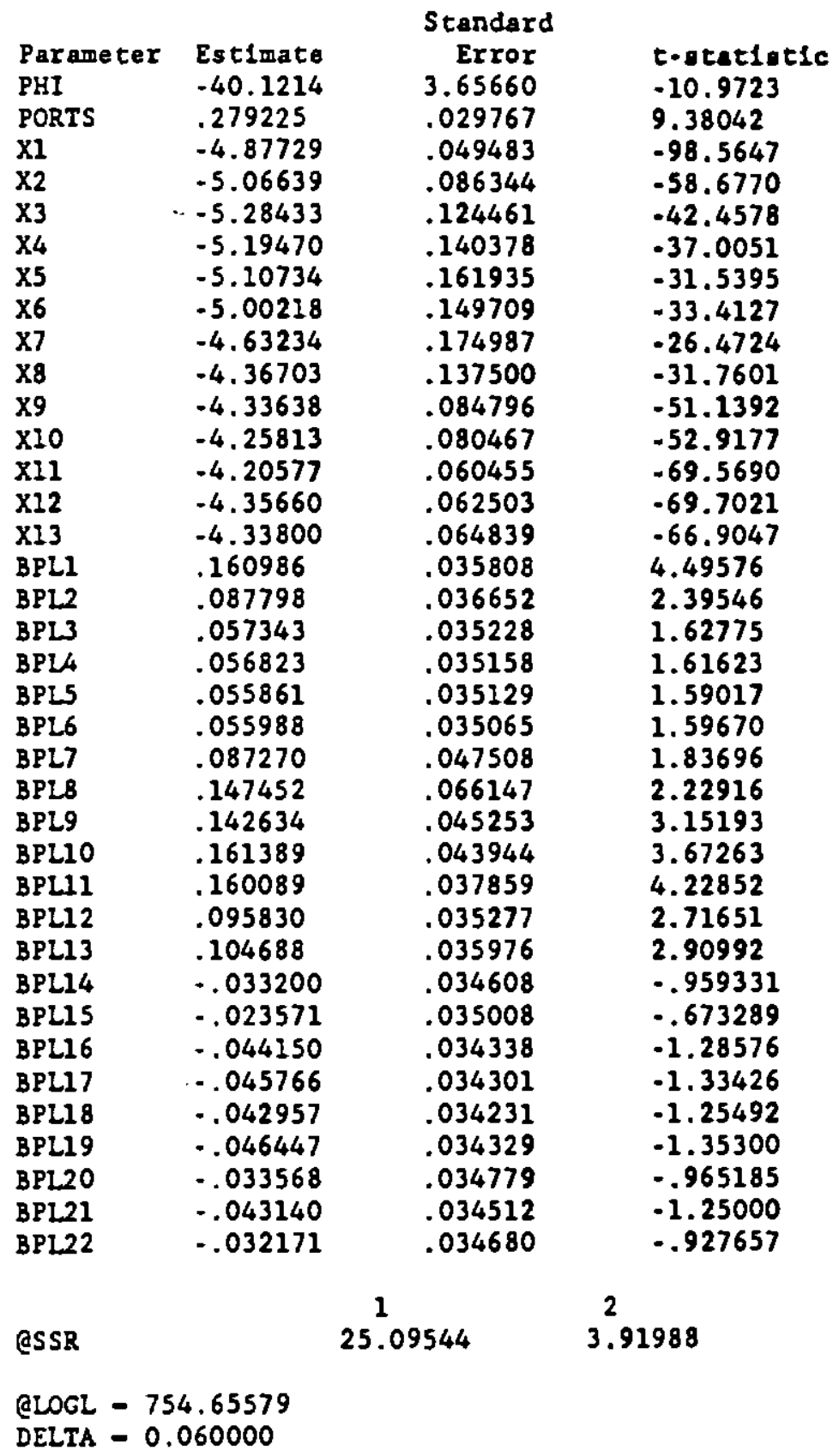


FINANCE 2

(value added, no IV'a, with Reglonal Dumnleg) NUMBER OF OBSERVATIONS - 598

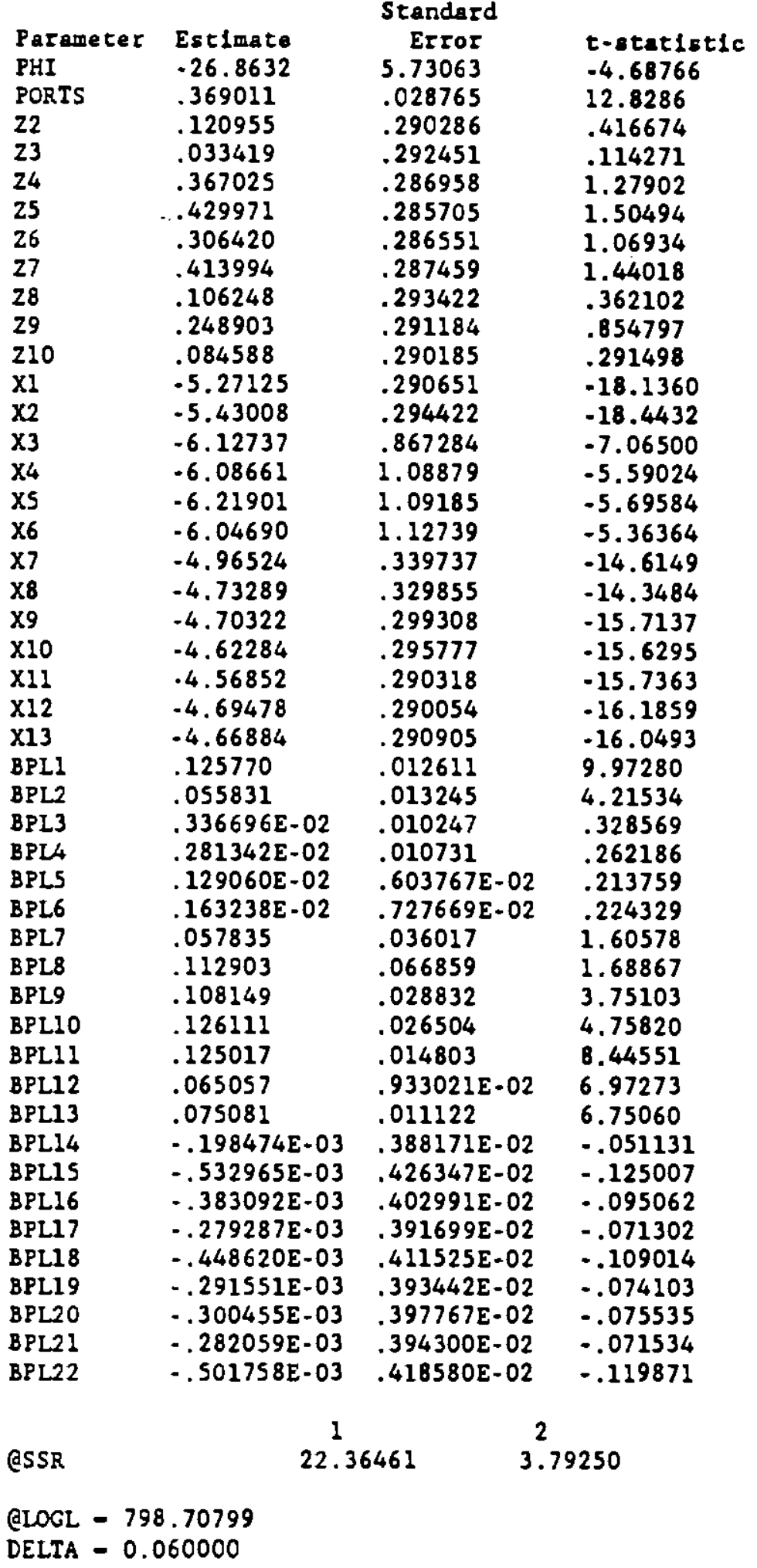


FINANCE 3

(value added, with IV's, no Reglonal Dummles) NUMBER OF OBSERVATIONS - 598

\begin{tabular}{|c|c|c|c|}
\hline Parameter & Estimate & Error & testetiatic \\
\hline PHI & -33.4004 & 13.4185 & -2.48912 \\
\hline PORIS & .389704 & .052811 & 7.37919 \\
\hline $\mathrm{Z2}$ & .085628 & .302521 & .283049 \\
\hline 23 & $\cdot .011614$ & .308851 & -.037605 \\
\hline 24 & .327414 & .297843 & 1.09928 \\
\hline 25 & .416246 & .298255 & 1.39560 \\
\hline Z6 & .284783 & .297529 & .957159 \\
\hline 27 & .383161 & .300965 & 1.27311 \\
\hline 28 & .043497 & .309571 & .140508 \\
\hline 29 & .192609 & .311282 & .618761 \\
\hline $\mathrm{Z} 10$ & .055399 & .301373 & .183821 \\
\hline$x 1$ & -4.28150 & .318891 & -13.4262 \\
\hline$x 2$ & -4.44021 & .320766 & -13.8425 \\
\hline$x^{3}$ & -5.80600 & 27.3718 & -.212116 \\
\hline$x 4$ & -5.78637 & 27.6187 & -.209509 \\
\hline X5 & -5.88747 & 27.6107 & -.213231 \\
\hline $\mathrm{x} 6$ & -5.72464 & 27.5949 & -.207453 \\
\hline$x 7$ & -3.96774 & .369222 & -10.7462 \\
\hline$x 8$ & -3.73448 & .363276 & -10.2800 \\
\hline$x 9$ & -3.70590 & .321785 & -11.5167 \\
\hline$x 10$ & -3.62370 & .320610 & -11.3025 \\
\hline $\mathrm{X} 11$ & .3 .56983 & .315311 & -11.3216 \\
\hline$X 12$ & -3.69708 & .316237 & -11.6909 \\
\hline$X 13$ & -3.66994 & .317067 & -11.5747 \\
\hline BPL1 & .125375 & .013246 & 9.46497 \\
\hline BPL2 & .055038 & .013638 & 4.03559 \\
\hline BPL3 & $.128170 \mathrm{E}-03$ & .012532 & .010227 \\
\hline BPL4 & $.813418 \varepsilon-04$ & $.802298 E-02$ & .010139 \\
\hline BPL5 & $.246099 \varepsilon-04$ & $.242981 \varepsilon-02$ & .010128 \\
\hline BPL6 & $.374476 \mathrm{E}-04$ & $.369324 \mathrm{E}-02$ & .010139 \\
\hline BPL7 & .057384 & .037147 & 1.54477 \\
\hline BPLB & .112575 & .066720 & 1.68729 \\
\hline BPL9 & .107802 & .028499 & 3.78261 \\
\hline BPL10 & .125780 & .027092 & 4.64263 \\
\hline BPL11 & .124700 & .014673 & 8.49865 \\
\hline BPL12 & .064868 & $.947309 \varepsilon-02$ & 6.84759 \\
\hline BPL13 & .074938 & .011566 & 6.47935 \\
\hline BPL14 & $-.498116 \mathrm{~g}-05$ & $.498953 \mathrm{E}-03$ & $-.998323 E-1$ \\
\hline BPL15 & $-.837274 \mathrm{E}-05$ & $.831752 \mathrm{E}-03$ &. .010066 \\
\hline BPL16 & $-.604460 \varepsilon-05$ & $.603047 \mathrm{E}-03$ & .010023 \\
\hline BPL17 & -.3134932 .05 & $.320362 E-03$ & $-.978558 \mathrm{E}-\mathrm{C}$ \\
\hline BPLI8 & $-.774113 \mathrm{E}-05$ & $.769366 \mathrm{E}-03$ &. .010062 \\
\hline BPL19 & $-.431722 \varepsilon-05$ & $.434741 \mathrm{E}-03$ & $-.993056 \mathrm{E}-\mathrm{C}$ \\
\hline BPL20 & $-.663467 \mathrm{E}-05$ & $.660865 \mathrm{E}-03$ & -.010039 \\
\hline BPL21 & $-.138670 \varepsilon-04$ & $.137185 E-02$ &. .010108 \\
\hline BPL22 &. $.583887 \mathrm{E} .05$ & $.583543 E-03$ &. .010006 \\
\hline
\end{tabular}




\begin{tabular}{|c|c|c|c|c|}
\hline BIN 1 & $.124735 E-05$ & $.234657 E-06$ & 5.31562 & \\
\hline BIN2 & $-.684529 \mathrm{E}-02$ & $.116072 E-02$ & -5.89743 & \\
\hline BIN3 & $.324694 E-02$ & $.354263 E-03$ & 9.16534 & \\
\hline BIN4 & $-.105424 E \cdot 04$ & $.354461 \mathrm{E}-05$ & -2.97420 & \\
\hline BIN5 & -.018886 & $.538620 E-02$ & -3.50631 & \\
\hline BIN6 & -.019041 & $.533295 E-02$ & -3.57039 & \\
\hline BIN7 & -.014269 & $.556383 E-02$ & -2.56463 & \\
\hline BIN8 & -.013648 & $.562440 \mathrm{~B}-02$ & -2.42660 & \\
\hline BIN9 & $-.721250 E-02$ & $.554565 \mathrm{E}-02$ & .1 .30057 & \\
\hline BIN10 &. .010492 & $.555196 \mathrm{E}-02$ & -1.88971 & \\
\hline BIN11 & -.020235 & $.544842 E-02$ & -3.71384 & \\
\hline BIN12 & -.020259 & $.540215 E-02$ & -3.75019 & \\
\hline BIN13 &. .020165 & $.535782 \mathrm{E}-02$ & -3.76365 & \\
\hline BIN14 & -.020468 & $.534268 E-02$ & -3.83100 & \\
\hline BIN15 & -.020553 & $.538678 \mathrm{E}-02$ & -3.81552 & \\
\hline BIN16 & -.020768 & $.542715 \mathrm{E}-02$ & -3.82675 & \\
\hline BIN17 & -.021132 & $.549047 \mathrm{E}-02$ & -3.84888 & \\
\hline eSSR & \multirow{2}{*}{\multicolumn{2}{|c|}{$\begin{array}{c}1 \\
51.95114\end{array}$}} & \multirow{2}{*}{$\begin{array}{l}2 \\
3.78606\end{array}$} & 3 \\
\hline essk & & & & 0.033678 \\
\hline
\end{tabular}


FINANCE 4

(value added, with IV's, with reglonal dummles) NUMBER OF OBSERVATIONS - 598

\begin{tabular}{|c|c|c|c|}
\hline Parameter & Estimate & $\begin{array}{l}\text { Standard } \\
\text { Error }\end{array}$ & $t$-otat 1 stic \\
\hline PHI & -30.7597 & 11.1182 & -2.76661 \\
\hline PORTS & .383088 & .044957 & 8.52113 \\
\hline 22 & .088440 & .335452 & .263644 \\
\hline 23 & -.012383 & .343512 &. .036048 \\
\hline 24 & .328298 & .334559 & .981285 \\
\hline 25 & .446467 & .347626 & 1.28433 \\
\hline 26 & .285490 & .334885 & .852501 \\
\hline 27 & .390760 & .336113 & 1.16259 \\
\hline 28 & .046030 & .342440 & .134419 \\
\hline 29 & .192109 & .339392 & .566039 \\
\hline 210 & .056346 & .340294 & .165581 \\
\hline $\mathrm{xI}$ & -4.29362 & .340187 & -12.6214 \\
\hline$\times 2$ & -4.44935 & .345129 & -12.8919 \\
\hline $\mathrm{x} 3$ & -5.86326 & 23.3949 & -.250621 \\
\hline$x_{4}$ & -5.96285 & 23.4660 & -.254105 \\
\hline$\times 5$ & -6.04382 & 23.4489 & -.257744 \\
\hline $\mathrm{x} 6$ & -5.87962 & 23.4338 & -.250903 \\
\hline $\mathrm{x7}$ & -3.97408 & .401569 & -9.89637 \\
\hline$x 8$ & -3.74302 & .382662 & -9.78154 \\
\hline $\mathrm{Xg}$ & -3.71456 & .347730 & -10.6823 \\
\hline$\times 10$ & -3.63191 & .347059 & -10.4648 \\
\hline $\mathrm{x} 11$ & -3.57792 & .342344 & -10.4513 \\
\hline $\mathrm{X} 12$ & -3.70427 & .344461 & -10.7538 \\
\hline $\mathrm{x} 13$ & $\cdot 3.67614$ & .343720 & -10.6951 \\
\hline BPLI & .125384 & .013698 & 9.15332 \\
\hline BPL2 & .055082 & .014412 & 3.82189 \\
\hline BPL3 & $.149746 \mathrm{E}-03$ & .012504 & .011976 \\
\hline BPL4 & $.556646 \mathrm{E}-04$ & $.466253 \mathrm{E}-02$ & .011939 \\
\hline BPL5 & $.254578 E-04$ & $.213232 \mathrm{E}-02$ & .011939 \\
\hline BPL6 & $.330701 E-04$ & $.276774 \mathrm{E}-02$ & .011948 \\
\hline BPL7 & .057545 & .040303 & 1.42780 \\
\hline BPL8 & .112589 & .067771 & 1.66131 \\
\hline BPL9 & .107802 & .029124 & 3.70154 \\
\hline BPLL1O & .125792 & .027611 & 4.55592 \\
\hline BPLI1 & .124679 & .017570 & 7.09608 \\
\hline BPL12 & .064824 & .011776 & 5.50468 \\
\hline BPL13 & .074926 & .010856 & 6.90168 \\
\hline BPL14 & $-.426332 \mathrm{E}-05$ & $.361114 \mathrm{E}-03$ & -.011806 \\
\hline BPL15 & $-.892753 E-05$ & $.750275 \mathrm{E}-03$ & -011899 \\
\hline BPL16 & $-.559083 \mathrm{E}-05$ & $.471813 \mathrm{E}-03$ & -.011850 \\
\hline BPLI7 & $-.196379 E-05$ & $.171785 E-03$ & .011432 \\
\hline BPL18 & $-.748722 \mathrm{E}-05$ & $.629893 E-03$ &. .011887 \\
\hline BPL19 & $-.358302 \mathrm{E}-05$ & $.305062 \mathrm{E}-03$ & -.011745 \\
\hline BPL2O & $-.592044 \mathrm{E}-05$ & $.499157 \mathrm{E}-03$ &. .011861 \\
\hline BPL.21 & $=398945 \mathrm{E}-05$ & $.338235 \mathrm{E}-03$ & $=.011795$ \\
\hline BPL.22 & $-.636464 E-05$ & $.536823 \mathrm{E}-03$ & -.011856 \\
\hline
\end{tabular}




$\begin{array}{llll}\text { Instrumental Var1able Equat1on } & \\ \text { BIN1 } & .591437 E-04 & .979830 E-05 & 6.03612 \\ \text { BIN2 } & -.073443 & .026564 & -2.76470 \\ \text { BIN3 } & .046126 & .014340 & 3.21668 \\ \text { BIN4 } & .553052 E-04 & .884803 E-04 & .625056 \\ \text { BIN5 } & -1.72526 & .251799 & -6.85173 \\ \text { BIN6 } & -1.72463 & .250897 & -6.87385 \\ \text { BIN7 } & -1.64180 & .250886 & -6.54399 \\ \text { BIN8 } & -1.61989 & .250482 & -6.46707 \\ \text { BIN9 } & -1.52079 & .249317 & -6.09980 \\ \text { BIN10 } & -1.56958 & .249444 & -6.29232 \\ \text { BIN11 } & -1.72684 & .254267 & -6.79145 \\ \text { BIN12 } & -1.72748 & .253614 & -6.81145 \\ \text { BIN13 } & -1.72722 & .251906 & -6.85661 \\ \text { BIN14 } & -1.72783 & .251964 & -6.85744 \\ \text { BIN15 } & -1.72863 & .252733 & -6.83975 \\ \text { BIN16 } & -1.73376 & .254408 & -6.81488 \\ \text { BIN17 } & -1.73174 & .252042 & -6.87084 \\ \text { BIN18 } & .972389 & .198238 & 4.90515 \\ \text { BIN19 } & .923518 & .210551 & 4.38619 \\ \text { BIN20 } & .899862 & .213192 & 4.22090 \\ \text { BIN21 } & 1.15131 & .221671 & 5.19376 \\ \text { BIN22 } & .832651 & .223450 & 3.72635 \\ \text { BIN23 } & .979981 & .227237 & 4.31259 \\ \text { BIN24 } & .864774 & .224078 & 3.85926 \\ \text { BIN25 } & .793807 & .235664 & 3.36839 \\ \text { BIN26 } & .810222 & .230375 & 3.51696\end{array}$
ESSR
1
2
37.55479
3.78603
11.64644
CLOGL - 1040.13569
DELTA $=0.030000$ 
FINANCE 5

(densitles, no IV's, with reglonal dumies) NUMBER OF OBSERVATIONS - 598

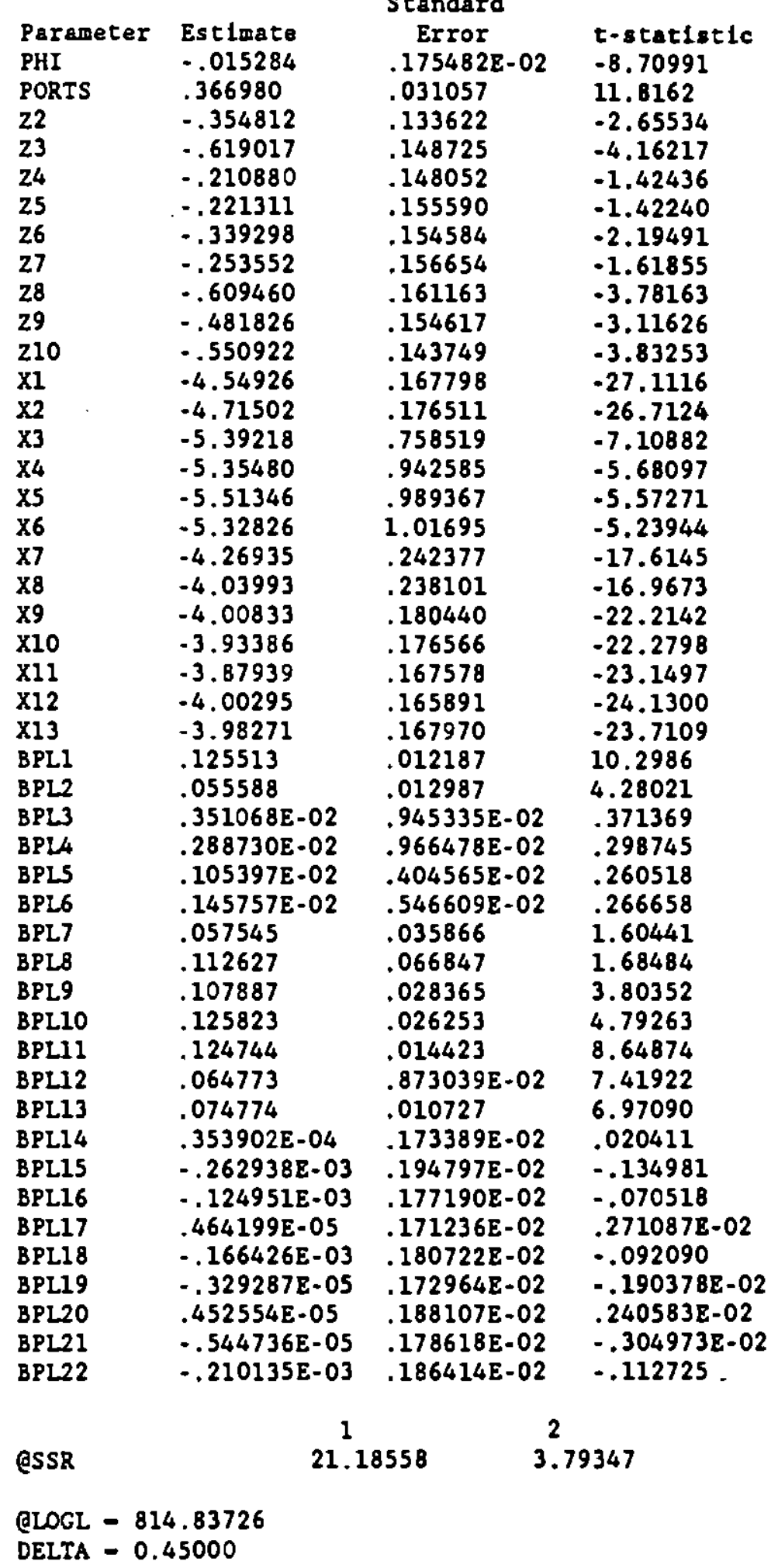


FINANCE 6

(densitles, with IV' with regional dumbles) NUMBER OF OBSERVATIONS - $\quad 598$

\begin{tabular}{|c|c|c|c|}
\hline Parameter & Estimate & $\begin{array}{c}\text { Standard } \\
\text { Error }\end{array}$ & t-atatiatic \\
\hline PHI & $\because 490420$ & .913730 & -.536723 \\
\hline PORTS & & $\begin{array}{r}.054759 \\
260662\end{array}$ & 7.15434 \\
\hline $\begin{array}{l}22 \\
23\end{array}$ & $\begin{array}{l}-.146759 \\
-.239045\end{array}$ & $\begin{array}{l}.360662 \\
.412487\end{array}$ & $\begin{array}{l}-.406914 \\
-.579521\end{array}$ \\
\hline 24 & .155062 & .397737 & .389842 \\
\hline 25 & $\ldots 316741$ & .348565 & .908698 \\
\hline 26 & .122644 & .398698 & .307612 \\
\hline 27 & .243257 & .363360 & .669465 \\
\hline 28 & -.189862 & .380395 & -.499119 \\
\hline 29 & -.040995 & .418138 & -.098042 \\
\hline 210 & -.149534 & .304110 &. .491710 \\
\hline$x 1$ & -4.09645 & .590895 & -6.93262 \\
\hline$x_{2}$ & -4.25048 & .586675 & -7.24504 \\
\hline$x^{3}$ & -5.74843 & 37.7723 & -.152186 \\
\hline$x_{4}$ & -5.97758 & 38.3872 &. .155718 \\
\hline$\times 5$ & -6.00979 & 38.3774 & -.156597 \\
\hline $\mathrm{x} 6$ & -5.84026 & 38.3611 & -.152244 \\
\hline$x 7$ & -3.77559 & .580456 & -6.50452 \\
\hline$\times 8$ & -3.54650 & .560365 & -6.32892 \\
\hline$x 9$ & -3.52132 & .534815 & -6.58419 \\
\hline$\times 10$ & -3.43930 & .518859 & -6.62859 \\
\hline$x 11$ & -3.39124 & .500242 & -6.77921 \\
\hline $\mathrm{x} 12$ & -3.52557 & .484904 & -7.27066 \\
\hline $\mathrm{X} 13$ & -3.50076 & .465924 & -7.51358 \\
\hline BPL1 & .125371 & .013803 & 9.08267 \\
\hline BPL2 & .055063 & .014048 & 3.91967 \\
\hline BPL3 & $.910529 \mathrm{E}-04$ & .012273 & $.741897 \mathrm{E}-02$ \\
\hline BPL4 & $.164411 E-04$ & $.225264 E-02$ & $.729860 \varepsilon-02$ \\
\hline BPLS & $.686989 \mathrm{E}-05$ & $.941170 \mathrm{E}-03$ & $.729931 E-02$ \\
\hline BPL6 & $.102946 \mathrm{E} \cdot 04$ & $.140965 \mathrm{E}-02$ & $.730296 E-02$ \\
\hline BPL7 & .057574 & .039609 & 1.45357 \\
\hline BPLB & .112592 & .067353 & 1.67168 \\
\hline BPL9 & .107800 & .028750 & 3.74957 \\
\hline BPLIO & .125795 & .028376 & 4.43315 \\
\hline BPL11 & .124676 & .019937 & 6.25352 \\
\hline BPL12 & .064834 & .011569 & 5.60406 \\
\hline BPL13 & .074927 & .011192 & 6.69495 \\
\hline BPL14 & $-.152322 E=06$ & $.229387 E=04$ & $-.664038 \mathrm{E}-02$ \\
\hline BPL15 & $-.821201 E-06$ & $.113439 E-03$ & $-.723912 \mathrm{E}-02$ \\
\hline BPL16 & $.124508 E-06$ & $.188370 \mathrm{E}-04$ & $.660975 E-02$ \\
\hline BPL17 & $.144456 E-05$ & $.197479 E-03$ & $.731499 \mathrm{E}-02$ \\
\hline BPL18 & $-.655681 E-06$ & $.906192 E-04$ & $-.723556 \mathrm{E}-02$ \\
\hline BPL19 & $.274883 E-06$ & $.381284 E-04$ & $.720941 E-02$ \\
\hline BPL20 & $-.419860 \mathrm{E}-06$ & $.587153 \mathrm{E}-04$ & $-.715078 E-02$ \\
\hline BPL21 & $.103778 \mathrm{E} \cdot 05$ & $.142697 E-03$ & $-.727261 E-02$ \\
\hline BPL22 & $-.582611 E-07$ & $.124886 E-04$ & $-.466515 E-02$ \\
\hline
\end{tabular}




\begin{tabular}{|c|c|c|c|}
\hline $\begin{array}{l}\text { BIN1 } \\
\text { BIN2 } \\
\text { BIN3 } \\
\text { BIN4 } \\
\text { BIN5 } \\
\text { BIN6 } \\
\text { BIN7 } \\
\text { BIN8 } \\
\text { BIN9 } \\
\text { BIN10 } \\
\text { BIN11 } \\
\text { BIN12 } \\
\text { BIN13 } \\
\text { BIN14 } \\
\text { BIN15 } \\
\text { BIN16 } \\
\text { BIN17 } \\
\text { BIN18 } \\
\text { BIN19 } \\
\text { BIN20 } \\
\text { BIN21 } \\
\text { BIN22 } \\
\text { BIN23 } \\
\text { BIN24 } \\
\text { BIN25 } \\
\text { BIN26 }\end{array}$ & $\begin{array}{l}. .973509 E-06 \\
.497923 E-03 \\
.253571 E-02 \\
.151730 \mathrm{E}-03 \\
.278944 \\
.270104 \\
.325409 \\
.335575 \\
.414452 \\
.380006 \\
.209303 \\
.194414 \\
.191698 \\
.174109 \\
.154902 \\
.135084 \\
.104913 \\
. .193829 \\
-.275376 \\
-.323006 \\
-.091618 \\
-.344637 \\
-.240600 \\
-.281678 \\
. .377194 \\
. .099505\end{array}$ & $\begin{array}{l}.952486 \mathrm{E}-05 \\
.022415 \\
.013043 \\
.756790 \mathrm{E}-04 \\
.232973 \\
.232156 \\
.231192 \\
.231108 \\
.231608 \\
.231246 \\
.235021 \\
.234418 \\
.233768 \\
.233198 \\
.234232 \\
.235929 \\
.236747 \\
.178693 \\
.194692 \\
.193601 \\
.194252 \\
.196669 \\
.201282 \\
.199289 \\
.208073 \\
.200446\end{array}$ & $\begin{array}{l}-.102207 \\
.022213 \\
.194409 \\
2.00491 \\
1.19732 \\
1.16346 \\
1.40752 \\
1.45203 \\
1.78945 \\
1.64329 \\
.890572 \\
.829348 \\
.820036 \\
.746616 \\
.661319 \\
.572561 \\
.443146 \\
-1.08470 \\
-1.41442 \\
-1.66841 \\
-.471645 \\
-1.75237 \\
-1.19534 \\
-1.41341 \\
-1.81279 \\
-.496418\end{array}$ \\
\hline @SSR & 52.0 & 7647 & 78594 \\
\hline
\end{tabular}

